\title{
Pharmacometabonomics: the prediction of drug effects using metabolic profiling
}

Jeremy R. Everett

Medway Metabonomics Research Group, University of Greenwich, Medway Campus, Central Avenue, Chatham Maritime, Kent ME4 4TB UK

j.r.everett@greenwich.ac.uk

\section{Keywords}

pharmacometabonomics, pharmacometabolomics, precision medicine, personalised medicine, metabonomics, metabolomics, metabotypes, metabolic phenotyping, systems medicine, NMR spectroscopy

\begin{abstract}
Metabonomics, also known as metabolomics, is concerned with the study of metabolite profiles in humans, animals, plants and other systems in order to assess their health or other status and their responses to experimental interventions. Metabonomics is thus widely used in disease diagnosis and in understanding responses to therapies such as drug administration. Pharmacometabonomics, also known as pharmacometabolomics, is a related methodology but with a prognostic as opposed to diagnostic thrust. Pharmacometabonomics aims to predict drug effects including efficacy, safety, metabolism and pharmacokinetics, prior to drug administration, via an analysis of pre-dose metabolite profiles. This article will review the development of pharmacometabonomics as a new field of science that has much promise in helping to deliver more effective personalised medicine, a major goal of $21^{\text {st }}$ century healthcare.
\end{abstract}

\section{Introduction}

Metabolic profiling of biological fluids has a long history going back hundreds, if not thousands, of years, to simple methods for detecting sweet-tasting urine as a biomarker for diabetes. (Burt and Nandal 2016; Lindon and Wilson 2016) The science of metabolic profiling developed rapidly in the 1980s as huge advances were made in the power and sensitivity of the nuclear magnetic resonance (NMR) spectroscopy and mass spectrometry (MS) detection technologies used in most metabolic profiling studies. Then in the late 1990s the sciences of metabonomics and metabolomics were 
named and defined. Metabonomics was defined in an interventional i.e. experimental paradigm by the groups of Jeremy Nicholson and Jeremy Everett at Birkbeck College/ Imperial College and Pfizer respectively as "the quantitative measurement of the multiparametric metabolic response of living systems to pathophysiological stimuli or genetic modification."(Lindon et al. 2000) The alternative term metabolomics was defined in an observational fashion a few years later by Fiehn as "a comprehensive analysis in which all the metabolites of a biological system are identified and quantified". (Fiehn 2002) The two terms are now used inter-operatively in spite of the stark differences between the definitions. The blanket term metabolic profiling is also used interchangeably with both terms. (Ed. Lindon 2019; Lindon et al. 2007)

Metabonomics has many uses in the clinical arena including studies of: disease mechanisms and biomarkers, disease diagnosis, detection of inborn errors of metabolism, the effects of therapeutic interventions on patients, drug metabolism, drug efficacy and drug safety.(Ed. Lindon 2019; Lindon et al. 2007) The experiments are typically performed using NMR and MS technologies to detect and identify large numbers of metabolites in biological fluids such as urine, blood plasma, sweat, cerebrospinal fluid, tears etc., but occasionally in body tissues as well. The metabolites detected in these metabonomics experiments are derived from a variety of sources including human endogenous, non-human endogenous (mainly the microbiome) and exogenous (external) sources including food, drink, drugs and the exposome.(Wild 2012) The phenotype of an organism is dictated by both the metabolites and the proteins that it contains and these may derive from many sources (Figure 1).

\begin{tabular}{|c|c|c|c|c|c|}
\hline \multicolumn{3}{|c|}{ metabolites } & \multicolumn{3}{|c|}{ proteins: functional and structural } \\
\hline $\begin{array}{c}\text { human } \\
\text { endogenous }\end{array}$ & $\begin{array}{l}\text { non-human } \\
\text { endogenous }\end{array}$ & $\begin{array}{c}\text { environmental } \\
\text { exogenous }\end{array}$ & $\begin{array}{c}\text { human } \\
\text { endogenous }\end{array}$ & $\begin{array}{l}\text { non-human } \\
\text { endogenous }\end{array}$ & $\begin{array}{c}\text { environmental } \\
\text { exogenous }\end{array}$ \\
\hline mets & & & & & \\
\hline pro & bacteriome & & $\begin{array}{c}\text { post- } \\
\text { translational } \\
\text { modification }\end{array}$ & & \\
\hline transc & mycome & food & transcriptome & & food \\
\hline epig & virome & drugs & ne & microbiome & drugs \\
\hline genome & parasitome & exposome & genome & parasitome & \\
\hline
\end{tabular}

Figure 1. The metabolites and proteins found in the human body may originate from inside the body (endogenous) or from various sources outside (exogenous). The pathway from gene to product is shown for the human endogenous metabolites and proteins, and the origins of non-human endogenous and exogenous metabolites and proteins are given. 
Metabonomics experiments are typically conducted in an interventional or a diagnostic paradigm. Differences in metabolite profiles following an experimental intervention such as drug treatment could be used to interpret the biological and biochemical effects of that treatment. In some cases, the intervention will produce a simple change, such as the reduction or increase in the concentration of one or a small number of key metabolites: these metabolites would thus be biomarkers for the effects of that intervention. In other cases, the intervention may produce widespread changes in the concentrations of a large number of metabolites and multivariate statistical analysis methods such as principal components analysis (PCA) can be used to simplify the data analysis and visualise the changes in metabolite space (Figure 2a). In this "event interpretation" mode of metabonomics, the changes from pre-intervention (open circles) to post-intervention metabolic state (black squares) are interpreted in relation to the nature of the intervention applied. Another typical use of metabonomics is to distinguish between different groups of subjects, e.g. patients with a disease, such as liver failure (orange squares), compared to age- and gender-matched healthy human controls (green circles, Figure $2 b$ ). In fact, the diagnostic paradigm of metabonomics is equivalent to the interventional paradigm if one considers that the intervention could be, for example, the presence or absence of a disease.

a

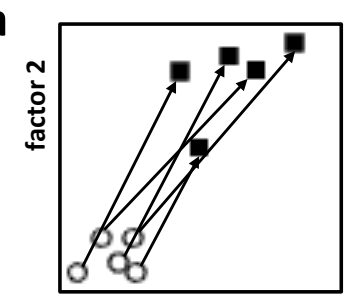

factor 1

metabonomics 1 (effect of intervention) b



factor 1

metabonomics 2

(diagnosis)



factor 1

pharmacometabonomics (prediction of intervention effects) (i.e. prognosis)

Figure 2. Schematic representations of the outcomes from the two key experimental approaches to metabolic phenotyping, based on multivariate analysis e.g. principal components scores, of the metabolic profiles of a number of individuals and showing the first two components (factor 1 and factor 2). Each square or circle represents an individual subject in the study. a) metabonomics approach 1 (effect of intervention), where open circles represent pre-intervention biofluid metabolic spectral profiles, and black squares represent postintervention metabolic profiles in the same individuals, where some metabolic perturbation has occurred. The arrows indicate the metabolic trajectory that each individual underwent across metabolic hyperspace as a consequence of the intervention; b) metabonomics approach 2: diagnosis. The metabolite profiles of patients with a disease (orange squares) are distinct from those of healthy controls (green circles) and thus a diagnosis can be made; c) the predictive or prognostic approach. The difference in the pre-intervention metabolic profiles of two sub-groups of subjects (white circles $v$ grey circles) allows prediction of different post-intervention states for 
these sub groups (red and blue squares respectively). For pharmacometabonomics, the intervention will be drug treatment and the prediction will be of drug PK, metabolism, efficacy or toxicity.

The technologies with which metabonomics experiments are conducted are important. There are two main technologies in use for metabolite detection and identification in biological fluids and tissues/tissue extracts today: mass spectrometry (MS), usually hyphenated together with a separation technology such as HPLC, UPLC, GC or CE, and NMR spectroscopy.(Ed. Lindon 2019; Lindon et al. 2007; Markley et al. 2017; Nicholson et al. 2016; Wehrens and Salek 2019; Wilson et al.) Good protocols and guides for conducting the experiments by MS(Chen et al. 2016; Scalbert et al. 2009) or NMR(Beckonert et al. 2007; Gowda and Raftery 2017) and good methodologies for identifying the metabolites by MS (Kind and Fiehn 2010; Watson 2013) or NMR(Dona et al. 2016; Markley et al. 2017) are available.

Metabonomics experiments typically analyse the concentrations of metabolites before and after an intervention (Figure 2a). Modern NMR spectrometers are capable of accurately quantifying the biofluid concentrations of dozens to hundreds of metabolites in a few minutes (Figure 3).



Figure 3. The $600 \mathrm{MHz}{ }^{1} \mathrm{H}$ NMR spectrum of the urine of a control, male C57BL/6 mouse together with expansions of two low frequency regions, demonstrating the large number of metabolites that can be detected. The identities of some key metabolites are given: 2OIV, 2-oxoisovalerate; 3M2OV, 3-methyl-2-oxovalerate; all, allantoin, cr, creatine; crn, creatinine; eth, ethanol; lac, lactate; DMA, dimethylamine; hipp, hippurate; MA, methylamine; succ, succinate; TMA, 
trimethylamine; TSP, trimethylsilylpropionate-d4 (the chemical shift and quantification reference); UP, ureidopropionate; water, the residual signal after water suppression.

A comparison of the attributes of MS and NMR for conducting metabonomics experiments is given in Table 1. Although far more studies are reported using MS-based detection (see Table 2 below), there is currently a trend to the increasing use of NMR due to its greater stability, ease of automation and reliability, which are increasingly important when dealing with large sample number studies, often the case in a clinical setting.

Table 1. The attributes and capabilities of mass spectrometry and NMR spectroscopy in metabonomics experiments.

\begin{tabular}{|c|c|}
\hline NMR spectroscopy & mass spectrometry \\
\hline $\begin{array}{l}\text { powerful structure elucidation capability for } \\
\text { small molecules in solution giving information } \\
\text { on molecular structure, isomerism, } \\
\text { conformations and dynamics }\end{array}$ & $\begin{array}{l}\text { - powerful structure analysis capability to } \\
\text { generate metabolite mass and molecular } \\
\text { fragment information together with molecular } \\
\text { formulae at high resolution }\end{array}$ \\
\hline $\begin{array}{l}\text { - relatively insensitive, but sensitivity improved } \\
\text { recently with digital spectrometers, } \\
\text { cryoprobes and low volume probes }\end{array}$ & - highly sensitive \\
\hline $\begin{array}{l}\text { - instrumentation expensive but per sample cost } \\
\text { relatively low }\end{array}$ & $\begin{array}{l}\text { instrumentation relatively inexpensive but } \\
\text { running costs high and isotopically-labelled } \\
\text { reference standards for quantitation can be } \\
\text { expensive }\end{array}$ \\
\hline $\begin{array}{l}\text { - absolute quantitative measurements and no } \\
\text { reference standard required when used with } \\
\text { ERETIC technology(Bharti and Roy 2012) }\end{array}$ & $\begin{array}{l}\text { not absolutely quantitative in absence of } \\
\text { specific reference standards, but has relative } \\
\text { quantification capability }\end{array}$ \\
\hline $\begin{array}{l}\text { - highly stable as no contact between sample } \\
\text { and spectrometer } \\
\text { - little effect of history on data } \\
\text { - suitable for large-scale experiments on } \\
\text { hundreds to thousands of samples in full } \\
\text { automation }\end{array}$ & $\begin{array}{l}\text { - relatively unstable, and may have detector gain } \\
\text { changes with large sample numbers } \\
\text { - column and spectrometer performance can be } \\
\text { affected by history } \\
\text { - large sample number runs are difficult due to } \\
\text { challenges of maintaining instrument stability }\end{array}$ \\
\hline $\begin{array}{l}\text { - minimal sample preparation and direct } \\
\text { analysis of biological samples }\end{array}$ & $\begin{array}{l}\text { - generally requires a chromatographic } \\
\text { separation step prior to MS analysis }\end{array}$ \\
\hline
\end{tabular}




\begin{tabular}{|c|c|}
\hline & $\begin{array}{l}\text { - gas chromatographic (GC) analysis requires } \\
\text { metabolite derivatisation in order to obtain } \\
\text { metabolite volatilisation }\end{array}$ \\
\hline $\begin{array}{l}\text { - one set of unique signals for each isomer of } \\
\text { each metabolite }\end{array}$ & $\begin{array}{l}\text { - soft ionisation mass spectra may be } \\
\text { complicated by multiple adduct formation with } \\
\text { multiple spectra for different metal ion and } \\
\text { solvent adducts observed for each metabolite } \\
\text { - GC-MS analyses may be complicated by } \\
\text { formation of multiple derivatives }\end{array}$ \\
\hline $\begin{array}{l}\text { - completely non-destructive technique: } \\
\text { samples can be stored and re-analysed }\end{array}$ & - sample destroyed in analysis \\
\hline
\end{tabular}

Metabonomics experiments can however be conducted not just by measuring metabolite concentrations or levels. Metabolite concentration trajectories through time, metabolite entropies and metabolite correlations or networks can also be measured (Figure 4) and these can often give additional information relative to that obtained from simple concentration measurements before and after an intervention.(Everett et al. 2019) 

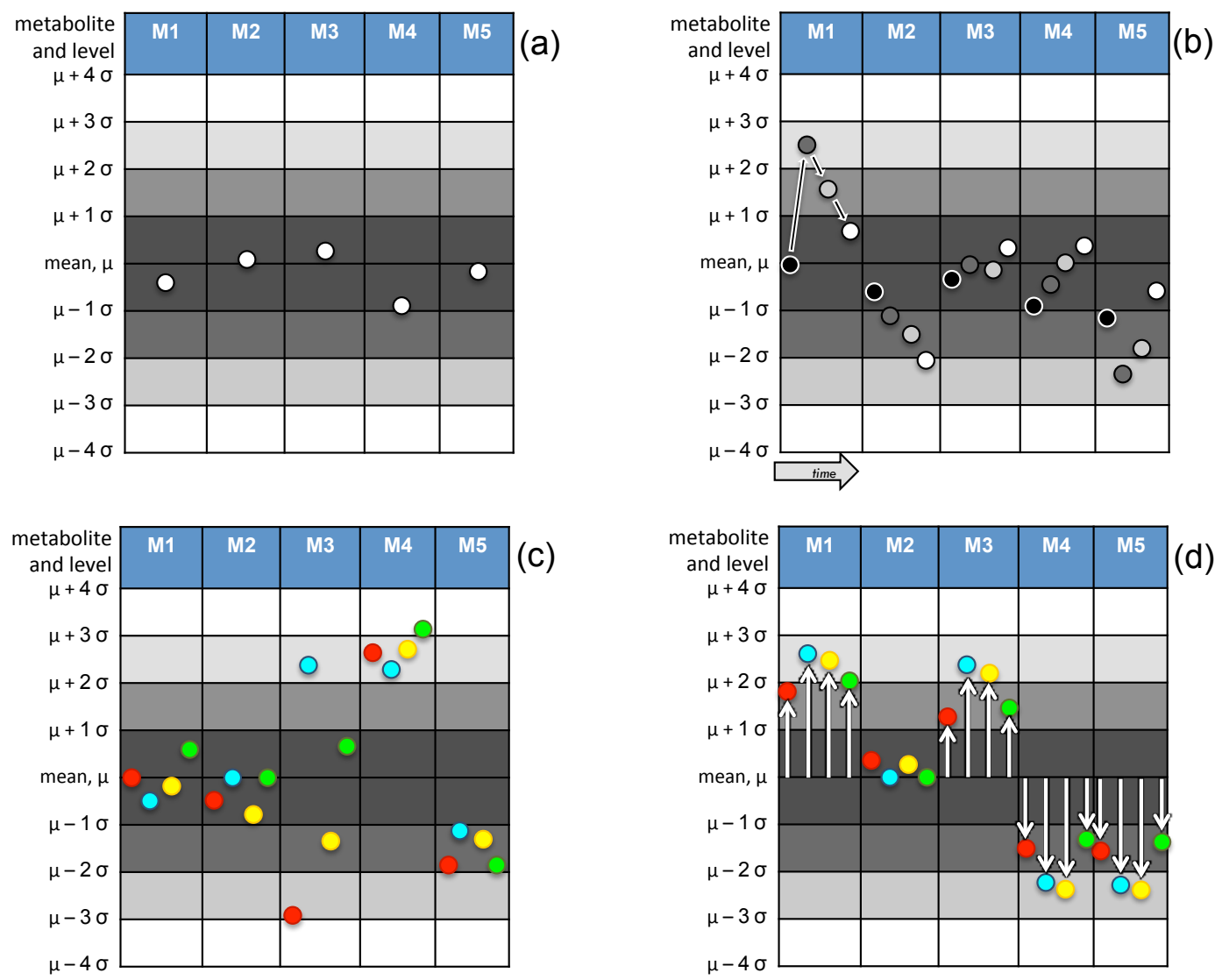

Figure 4. A schematic representation of the four principal approaches to the measurement of metabonomic data: via (a) metabolite levels, (b) trajectories, (c) entropies or (d) correlations/dependencies. In Box (a), the concentrations of 5 different metabolites M1 to M5 in one normal individual (white circles) are superimposed on a chart that represents the normal population distribution of metabolite concentrations. Symbols $\mu$ and $\sigma$ are the mean and standard deviations of the concentrations of the metabolites for that population and with normal distribution. In Box b, we see the trajectories of the concentrations over time for the same 5 metabolites M1 to M5 in one individual subjected to an intervention of some kind. The time course of the metabolic trajectory moves from left to right in each metabolite column and is represented by circles, whose shading gets lighter over time. Arrows connect the time points for metabolite M1 but others are omitted for clarity. It can be seen that as a result of the challenge, the levels of some metabolites (M1, M2 and M5) undergo positive and negative excursions from the normal population values, whereas other metabolites are less affected. In Box (c), the metabolic entropies of a cohort of four individuals that have been subjected to a challenge are represented. The metabolite concentration for each individual is colored differently (red, blue, yellow and green circles represent individuals 1, 2, 3 and 4 respectively). It can be seen that in this cohort there is high metabolic entropy for metabolite M3 (metabolite concentrations are distributed across a very wide range of values/ configurational states following the intervention) and significant disturbances in the metabolite concentrations for M4 and M5, but much lower metabolic entropy or disorder, for metabolites, M1, M2, M4 and M5. In Box (d), the metabolite correlations seen for 5 metabolites (M1 to M5) in 4 human subjects (red, blue, yellow and green circles represent individuals 1, 2, 3 and 4 respectively) are shown following an intervention. The intervention causes a significant increase in the concentrations of metabolite M1 for all four subjects (white vertical arrows), although to differing degrees. The 
same pattern of disturbance is seen for metabolite M3 in all four subjects. It is clear that the concentrations of metabolites M1 and M3 are correlated, with the excursions from the mean greatest for the yellow and blue subjects. By contrast the concentrations of metabolites M4 and M5 are anti-correlated with those of M1 and M3. It could be inferred from the correlations of the concentrations of these metabolites that they may be in the same or a related biochemical pathway. The levels of metabolite M2 are relatively undisturbed.

Metabonomics experiments are sometimes categorised as to whether they are targeted or untargeted.(Wishart 2016) In the targeted experiments, a selected group of metabolites is analysed, often quantifying the metabolite concentrations relative to an authentic reference standard. In the untargeted experiments, an unbiased approach is used and all the metabolites detected above the sensitivity threshold of the technology employed are analysed. Given the current lack of knowledge of mammalian biology and the complexities of genome - microbiome interactions, adopting a targeted approach to metabonomics is only recommended when there is a well-understood biological hypothesis regarding the subjects and the intervention of the experiment. Many surprising and important discoveries are to be made by untargeted methods because our understanding of mammalian biology is so primitive.

Metabonomics experiments can be conducted on a wide variety of sample types including biological fluids such as urine, blood plasma, cerebrospinal fluid, breath condensate, joint fluids etc.(Lindon et al. 2007) The choice of sample will influence the sort of information that the experiments can provide. Analysis of breath condensates will provide information on the large number of volatile, low molecular weight compounds in exchange with lung tissue, whereas the analysis of blood plasma will provide information on low molecular weight metabolites including sugars, organic acids and amino acids, together with macromolecular compounds such as proteins, glycoproteins and lipoproteins. The analysis of urine (Emwas et al. 2015) can be advantageous: it contains a wide variety of metabolites including amines, organic acids, amino acids and sugars and, in mammals, reports on both endogenous mammalian and endogenous microbial metabolites, mammalian microbial co-metabolites and exogenous metabolites. When the metabolism of a mammal such as a human is perturbed by disease or perhaps the effects of another intervention, such as drug treatment, the metabolic control systems will try to re-establish homeostasis. This will frequently occur by the elimination of unwanted metabolites via the urine, leaving the plasma less affected, thus giving the opportunity to identify the nature of the metabolic perturbation. Frequently, changes to the status of the gut microbiome can be detected by the observation of metabolic perturbations in urine samples. 
Although most metabonomics experiments are diagnostic or interventional in mode, some experiments can be prognostic; that is, the metabolite patterns observed can be used to predict future events. The rest of this chapter will be devoted to prognostic metabonomics.

\section{Discovery of Pharmacometabonomics}

A high degree of 'biological variation' i.e. widely varying results, was often observed in early drug metabolism and drug safety studies in Beecham Pharmaceuticals and Pfizer R \& D in the 1980s and 1990s. The causes of this variance were unknown but could lead to widely disparate results, sometimes to the extent that doubts were raised as to whether the drug in question had been dosed properly. Pfizer and Imperial College had established a panomics study of early drug safety signals in the 1990s. At a collaboration meeting in Amboise, France on $18^{\text {th }}$ October 2000, the topic of widely varying safety data on galactosamine and isoniazid was discussed. The notion emerged from the meeting that the metabolic phenotype of the animals prior to dosing was influencing differential responses to the drug post-dose. A series of experiments was designed to test this notion and the concept of pharmacometabonomics was born.

The first key experiment was to test the hypothesis that pre-dose rat metabolite profiles could predict post-dose drug metabolism and safety for the common analgesic paracetamol, also known as acetaminophen.(Clayton et al. 2006) A dose of $600 \mathrm{mg} / \mathrm{kg}$ was administered to 65 Sprague-Dawley rats and urine samples were collected both pre- and post-dosing and then analysed by $600 \mathrm{MHz}{ }^{1} \mathrm{H}$ NMR spectroscopy. A validated, superised projection to latent structure (PLS) model showed a statistically significant correlation between pre-dose urine metabolite concentrations and the postdose ratio of the metabolite paracetamol glucuronide $(\mathrm{G})$ to the parent drug paracetamol (P, Figure $5)$. 


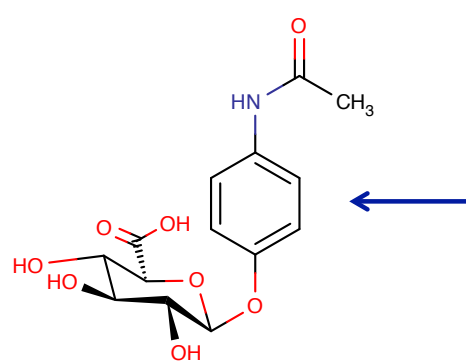

paracetamol glucuronide (G)<smiles>CC(=O)Nc1ccc(O)cc1</smiles>

paracetamol<smiles>CC(=O)Nc1ccc(O)c(SC[C@H](NC(C)=O)C(=O)O)c1</smiles>

paracetamol $\mathrm{N}$-acetyl-cysteine conjugate<smiles>CC(=O)Nc1ccc(OS(=O)(=O)O)cc1</smiles>

paracetamol sulphate $(S)$

Figure 5: the molecular structures of paracetamol (P) and its major metabolites.

In addition, unbiased principal components analysis (PCA) of the pre-dose urine ${ }^{1} \mathrm{H}$ NMR spectra showed a partial separation between the mean liver histopathology score (MHS) and principal component 2 (PC2) of the data (Figure 6).

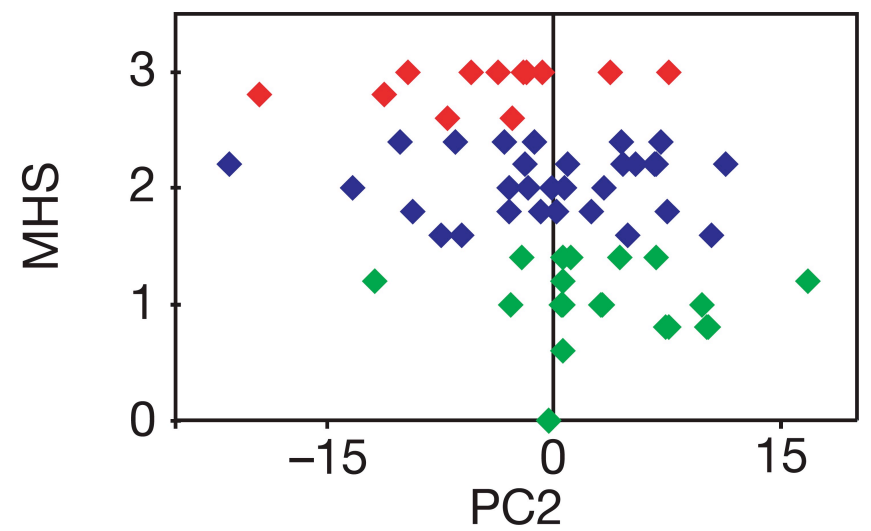

Figure 6: a plot of paracetamol liver toxicity as measured by the mean liver histopathology score (MHS) against principal component 2 (PC2) of the pre-dose urine NMR spectral data. A partial class separation is observed. Each point represents a single rat and is colour-coded by its histology class with increasing degree of liver pathology: class 1 is green (minimal / no pathology), class 2 is blue (intermediate pathology), class 3 is red (significant pathology). Figure reproduced from Nature Publishing Group (Clayton et al. 2006)

In addition a Mann-Whitney $U$-test showed the statistical significance of the separation of the predose NMR data for rats in class 1 (minimal/ no liver pathology) and class 3 (significant liver pathology) with $p=0.002$. The pre-dose levels of taurine were negatively correlated with the postdose degree of liver pathology, consistent with taurine's known role in protecting against 
paracetamol toxicity.(Waters et al. 2001) The taurine levels may have reflected the availability of inorganic sulphate to individual rats. Inorganic sulphate is needed for the biosynthesis of both taurine and for the paracetamol-sulphating agent phosphoadenosine phosphosulfate (PAPS). Consistent with this, rats with a high degree of liver necrosis showed a low degree of paracetamol sulphation.(Clayton et al. 2006)

Thus it was clearly demonstrated that pre-dose metabolite profiles could enable the prediction of post-dose effects including drug metabolism and toxicity. This is pharmacometabonomics, which was defined as 'the prediction of the outcome (for example, efficacy or toxicity) of a drug or xenobiotic intervention in an individual based on a mathematical model of pre-intervention metabolite signatures'.(Clayton et al. 2006) Pharmacometabonomics is a prognostic or predictive methodology, in contrast to the diagnostic mode of metabonomics and it is the metabolic equivalent of pharmacogenomics, which is the use of genetic information to predict drug effects in advance of dosing.(Salari et al. 2012)

The initial success of pharmacometabonomics experiments in animals prompted the question of whether the method would work in humans. A Pfizer / Imperial College research team therefore set up an experiment to test the hypothesis that pre-dose urine metabolite profiles could predict postdose drug metabolism, again in the analgesic paracetamol. A normal clinical dose of paracetamol (two $500 \mathrm{mg}$ tablets with water) was administered to 100, normal male volunteers in March and April 2003. Urine samples were collected both pre-dose and 0-3 and 3-6 hours post-dose and these were analysed by both $600 \mathrm{MHz}{ }^{1} \mathrm{H}$ NMR spectroscopy (Figure 7) and UPLC-MS.(Clayton et al. 2009) 

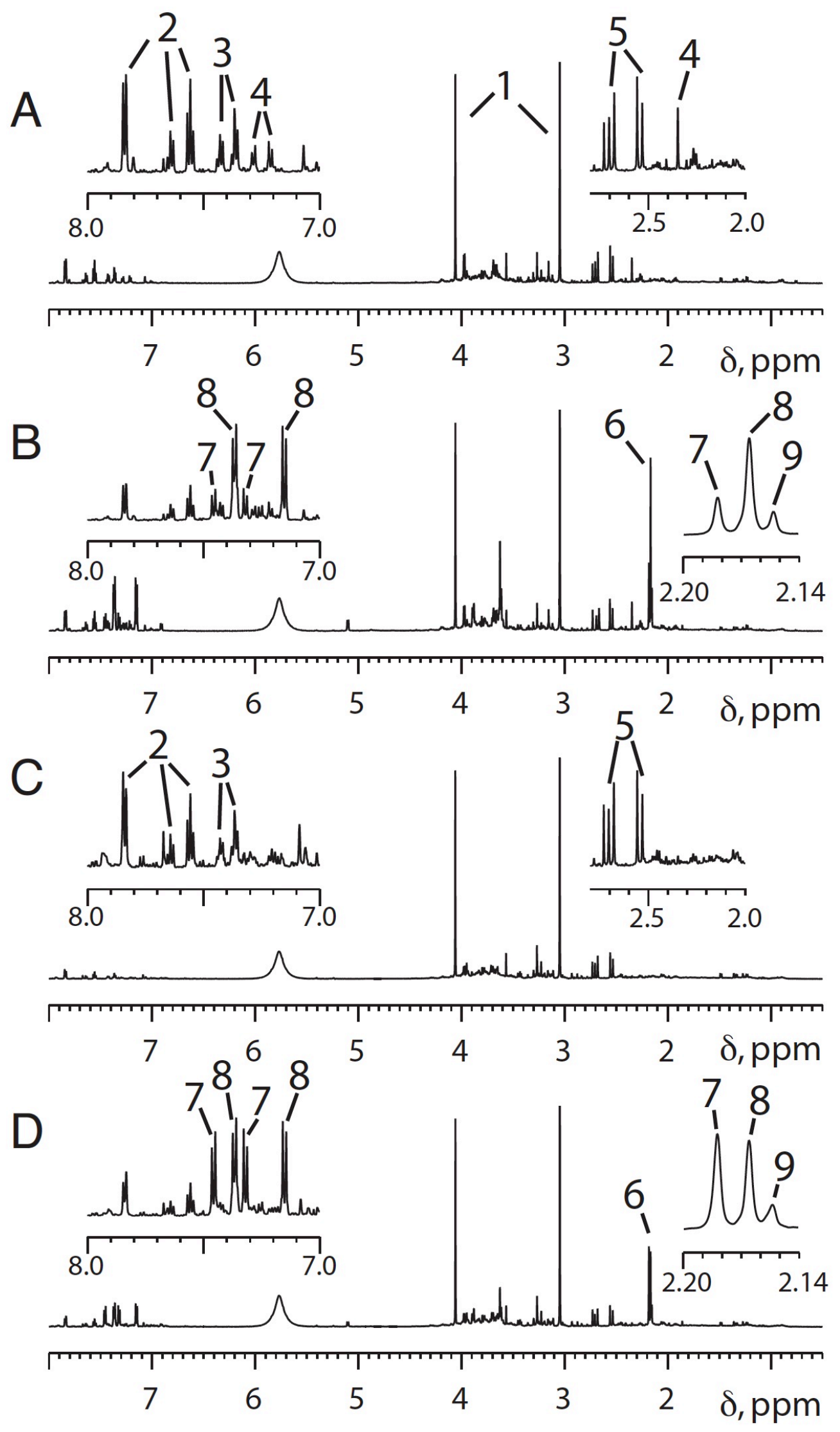

Figure 7: $600 \mathrm{MHz}{ }^{1} \mathrm{H}$ NMR spectra of the urines of volunteers taking a $1 \mathrm{~g}$ oral dose of paracetamol. A. spectrum of pre-dose urine of volunteer 1 together with expansions of the aromatic and lower frequency regions. B. 0-3 hour post- 
dose urine spectrum of volunteer 1. C and D: the corresponding pre-dose and post-dose urine spectra of volunteer 2 respectively. Key to NMR signal numbers: 1, creatinine; 2, hippurate; 3, phenylacetylglutamine; 4, unknown metabolite; 5, citrate; 6 , cluster of signals from $\mathrm{N}$-acetyl groups from paracetamol-related compounds that resolves into 7, 8 and 9 on expansion; 7, paracetamol sulfate; 8, paracetamol glucuronide; 9, other paracetamol-related compounds. Reproduced with permission from PNAS (Clayton et al. 2009)

The pre-dose ${ }^{1} \mathrm{H}$ NMR spectrum of volunteer 1 (Figure 7A) showed signals from microbial metabolites such as hippurate (2) and human metabolites such as citrate (5) in addition to an unknown metabolite (4) with a singlet methyl signal at ca $2.35 \mathrm{ppm}$ and second-order aromatic doublet signals between ca 7.2 and $7.3 \mathrm{ppm}$. This volunteer excreted more paracetamol glucuronide metabolite (8) than paracetamol sulphate (7) as is clear in the ${ }^{1} \mathrm{H}$ NMR spectrum of the $0-3$ hour post-dose urine (Figure 7B) where both methyl group singlet and second-order aromatic doublet signals for these metabolites are clearly visible. By contrast, volunteer 2 excreted no visible quantity of unknown metabolite 4 pre-dose but excreted a much higher ratio of paracetamol sulphate (7) to glucuronide (8) post-dose (Figure $7 \mathrm{C}$ and $\mathrm{D})$.

Analysis of the remaining urinary ${ }^{1} \mathrm{H}$ NMR data showed that this pattern was present across all of the volunteers (Figure 8).

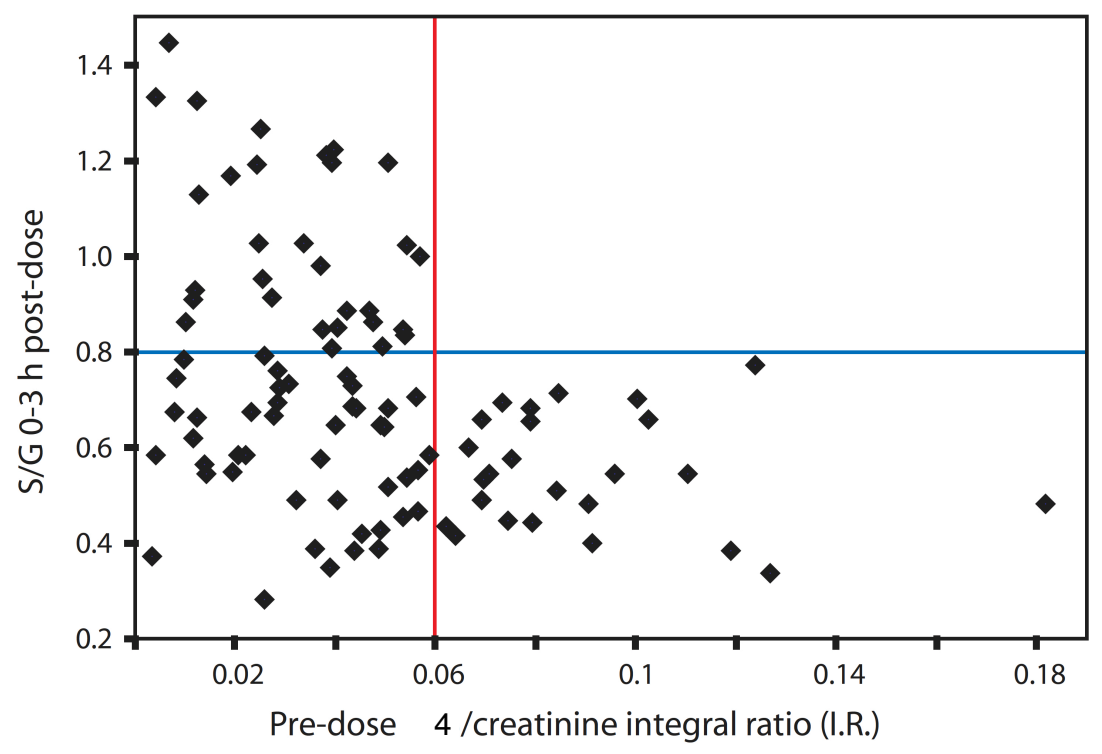

Figure 8: the urinary ratio of paracetamol sulphate $(\mathrm{S})$ to paracetamol glucuronide $(\mathrm{G})$ excreted 0 - 3 hours post-dose plotted against the pre-dose ratio of metabolite 4 normalised to creatinine. Reproduced with permission from PNAS.(Clayton et al. 2009)

It is clear from Figure 8 that when the pre-dose ratio of metabolite 4 normalised to creatinine is greater than 0.06 , then the post-dose paracetamol sulphate $(\mathrm{S})$ to paracetamol glucuronide $(\mathrm{G})$ ratio is always less than 0.8 . The same pattern was found when the 3-6 hour post-dose urines were analysed. 
Mann-Whitney $U$ tests in conjunction with a Bonferroni correction to counter the effects of multiple hypothesis testing showed that the association of high metabolite 4 to creatinine ratios with low S/G ratios was statistically significant for both the $0-3$ hour $(\mathrm{p}=0.0001)$ and 3-6 hour $(\mathrm{p}=0.00012)$ postdose urines. With a Bonferroni correction of 100 , the $p$ value for statistical significance is 0.0005 instead of 0.05.(Broadhurst and Kell 2006)

Thus, it was clear that there was a statistically significant correlation, between the presence of metabolite 4 at high levels pre-dose and diminished paracetamol sulphate (S) to paracetamol glucuronide $(\mathrm{G})$ ratios post-dose. It therefore became important to identify unknown metabolite 4.

Metabolite 4 possesses a singlet, three proton signal at ca $2.35 \mathrm{ppm}$ indicating the presence of a methyl group attached to an $\mathrm{sp}^{2}$ carbon on the basis of its chemical shift. The metabolite also possessed two, second-order aromatic doublet signals of two hydrogens each, indicating that metabolite 4 had a methyl group attached to a benzene ring with a substituent para to the methyl group. Metabolite 4 was identified as 4-cresolsulphate (HMDB11635)(Wishart et al. 2018) by both unambiguous chemical synthesis and spiking and by enzymatic desulphation to 4-cresol in situ (Figure 9).(Clayton et al. 2009)

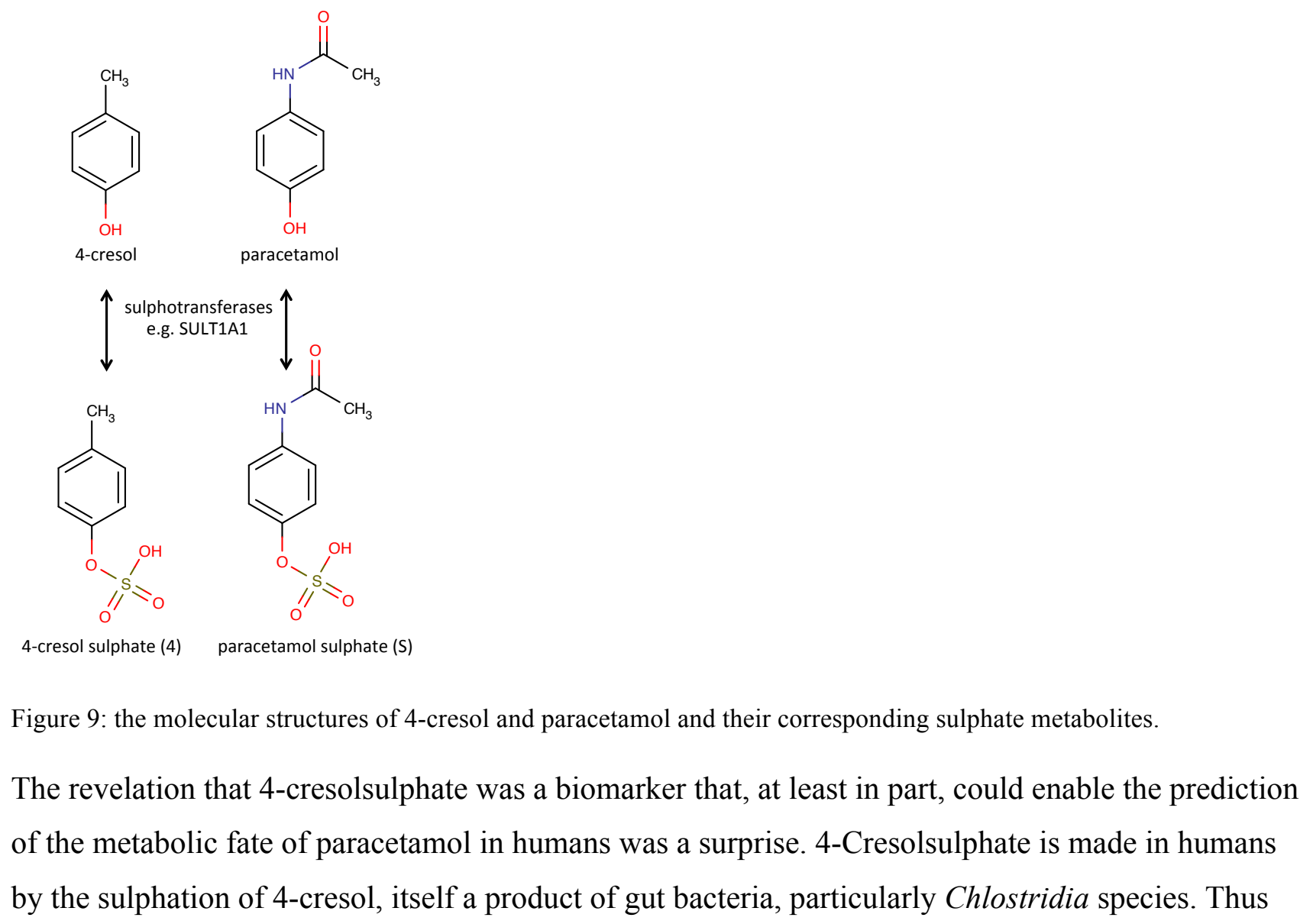


the human metabolism of the widely used analgesic paracetamol (acetaminophen) is at least in part under the control of gut bacterial metabolites. The influence of the gut microbiome on drug properties was not widely recognised at this time and this paper helped to highlight these important effects.(Wilson 2009)

The reason for the relationship between 4-cresol and paracetamol metabolism is evident from an inspection of Figure 9. The molecular structures of 4-cresol and paracetamol are quite similar and both are sulphated by the same sulphotransferases, particularly SULT1A1. In humans, as opposed to rodents, 4-cresol is metabolised almost exclusively by sulphation with no significant glucuronidation. However, this sulphation requires the sulphate donor cofactor 3-phosphoadenosine 5-phosphosulfate (PAPS) and its supply is limited in humans.(Gamage et al. 2006) Therefore in a human with a high 4-cresol burden due to their gut microbiome, a significant amount of PAPS is used in 4-cresol sulphation and a challenge to the body of that person of a large dose of a drug such as paracetamol, requiring sulphation, results in the body turning to the alternative elimination pathway of glucuronidation and the consequent decreased S/G metabolite ratios. Note that these findings have implications for all drugs metabolised by sulphation and implications also for endogenous metabolism involving sulphation. (Clayton et al. 2009) Finally, it is worth noting that a number of diseases including childhood autism, childhood hyperactivity and Parkinson's disease are associated with increased 4-cresolsulphate levels or altered S/G ratios after paracetamol administration and it is therefore likely that there is a microbiome influence on these disease states.(Clayton et al. 2009)

\section{Recent Developments in Pharmacometabonomics and the Delivery of Personalised Medicine}

The prediction of paracetamol metabolism and safety described above represented the first definitive demonstration of pharmacometabonomics. Since that study was published (Clayton et al. 2006) numerous other studies have emerged demonstrating the ability of pharmacometabonomics methodologies to predict drug pharmacokinetics, metabolism, efficacy and safety in animals and humans.(Burt and Nandal 2016; Everett 2016; Everett et al. 2016; Everett et al. 2013) These studies are important because they promise a new way to help deliver personalised medicine, which is a key objective of $21^{\text {st }}$ century healthcare.(Nicholson et al. 2016; Nicholson et al. 2011) The aim of personalised medicine is to select treatments that provide optimal efficacy with minimal toxicity or side effects for a given patient group, rather than giving the same standard treatment to all patients regardless of outcomes. It is a sobering fact that many drugs are ineffective or even unsafe in a high 
percentage of patients. It has been estimated that in the USA in 1994, over 2 million patients had serious adverse drug reactions (ADRs), resulting in hospitalisation, disability or, in 106,000 cases, death. (Lazarou et al. 1998) A more recent study put the cost of ADRs to the US economy in the range $\$ 30$ billion to $\$ 100$ billion per year. Thus the need to be able to prescribe medicines that are both effective and also safe for patients is clear.

Pharmacogenomics i.e. the use of patient genetic information to predict drug effects has been important in enabling the development of personalised medicine in some areas, especially in the prediction of the effects of 'drug metabolising' enzymes such as cytochrome P450s on drug efficacy and safety.(Lee et al. 2014) However, in many complex, multi-factorial diseases, the use of pharmacogenomics information has had more limited success.(Pirmohamed 2014) Given the impact of environmental factors on drug effects, such as the status of the gut microbiome (Clayton et al. 2009), and the impact of drug-drug interactions, especially in phenoconversion,(Shah and Smith 2015) it is not surprising that human pharmacogenomics studies have encountered challenges in progressing from success in the laboratory to success in clinical practice.(Pirmohamed 2014) It is therefore encouraging that metabolic studies in the form of pharmacometabonomics can assist in the prediction of drug effects and with the implementation of personalised medicine. We will review progress in this area in the remainder of this chapter.

Table 2 provides an overview of the key pharmacometabonomics and predictive metabonomics studies that we are aware of, using the keywords pharmacometabonomics and pharmacometabolomics in PubMed. However, the list is unlikely to be exhaustive, as some authors do not put these terms in either the title or keyword list. In addition, there are a minority of authors who are using the term pharmacometabonomics or pharmacometabonomics to describe diagnostic metabonomics experiments with no prognostic elements.

Table 2: A list of pharmacometabonomics studies from 2006 to 2019, sorted by study type and date order

\begin{tabular}{|c|c|c|c|}
\hline \# & study and reference & species & $\begin{array}{l}\text { metabolite } \\
\text { profiling } \\
\text { technology }\end{array}$ \\
\hline & prediction of pharmaco-kinetics (PK) & & \\
\hline 1 & $\begin{array}{l}\text { prediction of tacrolimus PK in healthy volunteers (Phapale } \\
\text { et al. 2010) }\end{array}$ & human & LC-MS \\
\hline 2 & $\begin{array}{l}\text { prediction of pharmacokinetics of triptolide (Liu et al. } \\
\text { 2012) }\end{array}$ & rat & GC-MS \\
\hline 3 & prediction of atorvastatin pharmacokinetics in healthy & human & GC-MS \\
\hline
\end{tabular}




\begin{tabular}{|c|c|c|c|}
\hline & volunteers (Huang et al. 2015) & & \\
\hline 4 & $\begin{array}{l}\text { prediction of methotrexate clearance in patients with } \\
\text { lymphoid malignancies (Kienana et al. 2016) }\end{array}$ & human & GC-MS \\
\hline 5 & $\begin{array}{l}\text { prediction of midazolam clearance in female volunteers } \\
\text { (Shin et al. 2016) }\end{array}$ & human & GC-MS \\
\hline 6 & $\begin{array}{l}\text { pharmacometabonomic prediction of busulphan clearance } \\
\text { in hematopoietic stem cell transplant recipients (Navarro et } \\
\text { al. 2016) }\end{array}$ & human & LC-MS \\
\hline 7 & $\begin{array}{l}\text { prediction of Intravenous Busulfan Clearance by } \\
\text { Endogenous Plasma Biomarkers Using Global } \\
\text { Pharmacometabolomics (Lin et al. 2016) }\end{array}$ & human & LC-MS \\
\hline 8 & $\begin{array}{l}\text { prediction of busulphan AUC in hematopoietic stem cell } \\
\text { transplantation patients (Kim et al. 2017) }\end{array}$ & human & LC-MS \\
\hline 9 & $\begin{array}{l}\text { prediction of d4-cholic acid pharmacokinetics (Zhang et al. } \\
2017 \text { b) }\end{array}$ & rat & LC-MS \\
\hline 10 & $\begin{array}{l}\text { integrated use of pharmacometabonomics and } \\
\text { pharmacogenomics to predict the pharmacokinetics of a } \\
\text { novel transient receptor potential vanilloid type } 1 \text { (TRPV1) } \\
\text { antagonist(Oh et al. } 2018 \text { ) }\end{array}$ & human & LC-MS \\
\hline 11 & $\begin{array}{l}\text { prediction of zonisamide pharmacokinetics parameters in } \\
\text { volunteers (Martinez-Avila et al. 2018a; Martinez-Avila et } \\
\text { al. } 2018 \text { b) }\end{array}$ & human & LC-MS \\
\hline 12 & $\begin{array}{l}\text { prediction of methylphenidate PK in healthy volunteers } \\
\text { (Kaddurah-Daouk et al. 2018) }\end{array}$ & human & LC-MS \\
\hline \multirow[t]{2}{*}{13} & $\begin{array}{l}\text { prediction of midazolam clearance in male volunteers (Lee } \\
\text { et al. 2019) }\end{array}$ & human & GC-MS \\
\hline & prediction of drug metabolism & & \\
\hline 1 & $\begin{array}{l}\text { prediction of paracetamol/acetaminophen metabolism } \\
\text { (Clayton et al. 2006) } \\
* * \text { first demonstration of pharmacometabonomics }\end{array}$ & rat & NMR \\
\hline 2 & $\begin{array}{l}\text { prediction of metabolism of paracetamol / acetaminophen } \\
\text { in human volunteers (Clayton et al. 2009) } \\
* * \text { first demonstration of pharmacometabonomics in } \\
\text { humans }\end{array}$ & human & NMR \\
\hline 3 & $\begin{array}{l}\text { prediction of CYP3A4 induction in volunteer twins } \\
\text { (Rahmioglu et al. 2011) }\end{array}$ & human & NMR \\
\hline 4 & $\begin{array}{l}\text { prediction of CYP3A activity in healthy volunteers (Shin } \\
\text { et al. 2013) }\end{array}$ & human & GC-MS \\
\hline 5 & $\begin{array}{l}\text { prediction of Losartan metabolism in healthy volunteers } \\
\text { (He et al. 2018) }\end{array}$ & human & $\begin{array}{l}\text { NMR and } \\
\text { LC-MS }\end{array}$ \\
\hline 6 & $\begin{array}{l}\text { prediction of methylphenidate (Ritalin [for ADHD]) } \\
\text { metabolism in healthy genotyped volunteers (Kaddurah- } \\
\text { Daouk et al. 2018) }\end{array}$ & human & LC-MS \\
\hline & & & \\
\hline
\end{tabular}




\begin{tabular}{|c|c|c|c|}
\hline & prediction of drug efficacy & & \\
\hline 1 & $\begin{array}{l}\text { prediction of simvastatin efficacy in patients on the } \\
\text { Cholesterol and Pharmacogenomics study (Kaddurah- } \\
\text { Daouk et al. 2010; Trupp et al. 2012) }\end{array}$ & human & $\begin{array}{l}\text { TLC plus GC } \\
\text { and GC-MS }\end{array}$ \\
\hline 2 & $\begin{array}{l}\text { prediction of chemotherapy efficacy in breast cancer } \\
\text { patients (Stebbing et al. 2012) }\end{array}$ & human & NMR \\
\hline 3 & $\begin{array}{l}\text { prediction of citalopram/ escitalopram response in patients } \\
\text { with major depressive disorder (MDD) (Ji et al. 2011) } \\
* * \text { first demonstration of pharmacometabonomics- } \\
\text { informed pharmacogenomics approach to personalised } \\
\text { medicine } \\
\text { See also (Abo et al. 2012) and (Gupta et al. 2016) }\end{array}$ & human & $\begin{array}{l}\text { GC-MS and } \\
\text { LC-ECA (LC- } \\
\text { electrochemic } \\
\text { al coulometric } \\
\text { array } \\
\text { detection) }\end{array}$ \\
\hline 4 & $\begin{array}{l}\text { prediction of sertraline and placebo responses in patients } \\
\text { with MDD (Kaddurah-Daouk et al. 2011), (Kaddurah- } \\
\text { Daouk et al. 2013) and (Zhu et al. 2013) }\end{array}$ & human & $\begin{array}{l}\text { LC-ECA and } \\
\text { GC-MS }\end{array}$ \\
\hline 5 & $\begin{array}{l}\text { prediction of efficacy of anti-psychotics in schizophrenia } \\
\text { patients (Condray et al. 2011) }\end{array}$ & human & LC-ECA \\
\hline 6 & $\begin{array}{l}\text { prediction of response to aspirin in healthy volunteers } \\
\text { (Ellero-Simatos et al. 2014; Lewis et al. 2013; Yerges- } \\
\text { Armstrong et al. 2013) }\end{array}$ & human & $\begin{array}{l}\text { LC-MS and } \\
\text { GC-MS }\end{array}$ \\
\hline 7 & $\begin{array}{l}\text { prediction of efficacy with anti-TNF therapies in } \\
\text { rheumatoid arthritis (Kapoor et al. 2013) }\end{array}$ & human & NMR \\
\hline 8 & $\begin{array}{l}\text { prediction of thiopurine-S-methyltransferase phenotype in } \\
\text { Estonian volunteers (Karas-Kuzelicki et al. 2014) }\end{array}$ & human & HPLC \\
\hline 9 & $\begin{array}{l}\text { prediction of efficacy of L-carnitine therapy for patients } \\
\text { with sepsic shock (Evans et al. 2019; Puskarich et al. 2018; } \\
\text { Puskarich et al. 2015) }\end{array}$ & human & $\begin{array}{l}\text { NMR and LC- } \\
\text { MS }\end{array}$ \\
\hline 10 & $\begin{array}{l}\text { prediction of acamprosate treatment outcomes in alcohol- } \\
\text { dependent patients (Nam et al. 2015) }\end{array}$ & human & LC-MS \\
\hline 11 & $\begin{array}{l}\text { prediction of blood pressure lowering in hypertensive } \\
\text { patients treated with atenolol and hydrochlorothiazide } \\
\text { (Rotroff et al. 2015) }\end{array}$ & human & GC-MS \\
\hline 12 & $\begin{array}{l}\text { prediction of response in lung cancer patients (Hao et al. } \\
2016 \text { a) }\end{array}$ & human & $\begin{array}{l}\text { NMR and GC- } \\
\text { MS }\end{array}$ \\
\hline 13 & $\begin{array}{l}\text { prediction of patient response to trastuzumab-paclitaxel } \\
\text { neoadjuvant therapy in HER-2 positive breast cancer } \\
\text { (Miolo et al. 2016) }\end{array}$ & human & LC-MS \\
\hline 14 & $\begin{array}{l}\text { prediction of patient response in SSRI treatment of major } \\
\text { depressive disorder (Gupta et al. 2016) }\end{array}$ & human & LC-ECA \\
\hline 15 & $\begin{array}{l}\text { prediction of Clopidogrel high on treatment platelet } \\
\text { reactivity (HTPR) in CAD patients [NMR] (Amin et al. } \\
2017 \text { ) }\end{array}$ & human & NMR \\
\hline 16 & $\begin{array}{l}\text { prediction of chemosensitivity of treatment of AML } \\
\text { patients with cytarabine and anthracycline (Tan et al. } \\
\text { 2017) }\end{array}$ & human & LC-MS \\
\hline 17 & $\begin{array}{l}\text { prediction of efficacy in pancreatic ductal adenocarcinoma } \\
\text { patients receiving gemcitabine (Phua et al. 2017) }\end{array}$ & human & GC-TOFMS \\
\hline
\end{tabular}




\begin{tabular}{|c|c|c|c|}
\hline 18 & $\begin{array}{l}\text { prediction of blood pressure lowering by } \\
\text { hydrochlorothiazide [lipidomics and pharmacogenomics] } \\
\text { (Shahin et al. 2017) }\end{array}$ & human & \\
\hline 19 & $\begin{array}{l}\text { prediction of efficacy of gemcitabine and carboplatin } \\
\text { treatment of metastatic breast cancer patients (Jiang et al. } \\
\text { 2018) }\end{array}$ & human & NMR \\
\hline 20 & $\begin{array}{l}\text { prediction of gemcitabine efficacy in pancreatic ductal } \\
\text { adenocarcinoma patients (Phua et al. 2018) }\end{array}$ & human & GC-MS \\
\hline 21 & $\begin{array}{l}\text { prediction of response to metformin treatment in early } \\
\text { T2DM patients (Park et al. 2018) }\end{array}$ & human & GC-MS \\
\hline 22 & $\begin{array}{l}\text { prediction of efficacy of propranolol in reducing hepatic } \\
\text { venous pressure gradient (HPVG) in patients with liver } \\
\text { cirrhosis (Reverter et al. 2019) }\end{array}$ & human & LC-MS \\
\hline 23 & $\begin{array}{l}\text { prediction of efficacy of meglumine antimonite efficacy if } \\
\text { patients with cutaneous Leishmaniasis (Alejandro Vargas } \\
\text { et al. 2019) }\end{array}$ & human & LC-MS \\
\hline 24 & $\begin{array}{l}\text { QUASI-prediction of dexamethasone steroid treatment } \\
\text { efficacy in pre-term infants with respiratory syndrome } \\
\text { (Cao et al. 2019) }\end{array}$ & human & GC-TOF-MS \\
\hline 25 & $\begin{array}{l}\text { prediction of warfarin efficacy in atrial fibrillation patients } \\
\text { (Bawadikji et al. 2019) }\end{array}$ & human & NMR \\
\hline & prediction of adverse events & & \\
\hline 1 & $\begin{array}{l}\text { prediction of toxicity from paracetamol/acetaminophen } \\
\text { dosing (Clayton et al. 2006) } \\
* * \text { first demonstration of pharmacometabonomics }\end{array}$ & rat & NMR \\
\hline 2 & $\begin{array}{l}\text { prediction of weight gain in breast cancer patients } \\
\text { undergoing chemotherapy (Keun et al. 2009) } \\
* * \text { first demonstration of pharmacometabonomics in } \\
\text { patients }\end{array}$ & human & NMR \\
\hline 3 & $\begin{array}{l}\text { prediction of onset of diabetes in rats administered with } \\
\text { streptozotocin (Li et al. 2007) }\end{array}$ & rat & GC-MS \\
\hline 4 & $\begin{array}{l}\text { prediction of liver injury markers in patients treated with } \\
\text { ximelagatran (Andersson et al. 2009) }\end{array}$ & human & $\begin{array}{l}\text { NMR, GC-MS } \\
\text { and LC-MS }\end{array}$ \\
\hline 5 & $\begin{array}{l}\text { prediction of toxicity of paracetamol / acetaminophen } \\
\text { ('early-onset pharmacometabonomics') (Winnike et al. } \\
\text { 2010) }\end{array}$ & human & NMR \\
\hline 6 & $\begin{array}{l}\text { prediction of nephrotoxicity of cisplatin (Kwon et al. } \\
\text { 2011) }\end{array}$ & rat & NMR \\
\hline 7 & $\begin{array}{l}\text { prediction of toxicity in patients with inoperable colorectal } \\
\text { cancer treated with capecitabine (Backshall et al. 2011) }\end{array}$ & human & NMR \\
\hline 8 & $\begin{array}{l}\text { prediction of toxicity of isoniazid in rats (Cunningham et } \\
\text { al. 2012) }\end{array}$ & rat & NMR \\
\hline 9 & $\begin{array}{l}\text { prediction of hyperglycaemia in Caucasian hypertensive } \\
\text { patients on the PEAR study with atenolol (Weng et al. } \\
\text { 2016) }\end{array}$ & human & LC-MS \\
\hline
\end{tabular}




\begin{tabular}{|c|c|c|c|}
\hline 10 & $\begin{array}{l}\text { prediction of variability in response to galactosamine } \\
\text { treatment (Coen et al. 2012) }\end{array}$ & rat & NMR \\
\hline 11 & $\begin{array}{l}\text { prediction of hyperglycaemia in Caucasian hypertensive } \\
\text { patients on the PEAR study with atenolol (de Oliveira et } \\
\text { al. 2016) }\end{array}$ & human & $\begin{array}{l}\text { GC-TOF-MS } \\
\text { and genomics }\end{array}$ \\
\hline 12 & $\begin{array}{l}\text { prediction of toxicity from lipopolysaccharide treatment in } \\
\text { rats (Dai et al. 2016) }\end{array}$ & rat & $\begin{array}{l}\text { LC-MS and } \\
\text { GC-MS }\end{array}$ \\
\hline 13 & $\begin{array}{l}\text { prediction of 'high on treatment platelet reactivity } \\
\text { (HTPR)' in patients on clopidogrel anti-platelet therapy to } \\
\text { prevent stent thrombosis in urine (Amin et al. 2017) }\end{array}$ & human & NMR \\
\hline 14 & $\begin{array}{l}\text { prediction of nephrotoxicity of cisplatin in rats (Zhang et } \\
\text { al. 2017a) }\end{array}$ & rat & $\begin{array}{l}\text { GC-MS and } \\
\text { LC-MS }\end{array}$ \\
\hline 15 & $\begin{array}{l}\text { prediction of 'high on treatment platelet reactivity } \\
\text { (HTPR)' in patients on clopidogrel anti-platelet therapy to } \\
\text { prevent stent thrombosis in plasma (Amin et al. 2018) }\end{array}$ & human & NMR \\
\hline 16 & $\begin{array}{l}\text { prediction of peripheral neuropathy in breast cancer } \\
\text { patients treated with Paclitaxel (Sun et al. 2018) }\end{array}$ & human & NMR \\
\hline 17 & $\begin{array}{l}\text { prediction of irinotecan gastrointestinal toxicity (Gao et al. } \\
2019 \text { ) }\end{array}$ & rat & $\begin{array}{l}\text { GC-MS and } \\
\text { LC-MS }\end{array}$ \\
\hline & predictive metabonomics & & \\
\hline 1 & $\begin{array}{l}\text { prediction of developing diabetes (Wang et al. 2011) } \\
* * \text { first predictive metabonomics study }\end{array}$ & Human & LC-MS \\
\hline 2 & prediction of pre-diabetes (Wang-Sattler et al. 2012) & Human & $\begin{array}{l}\text { LC-MS and } \\
\text { flow-injection } \\
\text { analysis-MS }\end{array}$ \\
\hline 3 & $\begin{array}{l}\text { prediction of renal function recovery after relief of } \\
\text { obstructive uropathy (Dong et al. 2013) }\end{array}$ & Human & NMR \\
\hline 4 & prediction of all-cause death (Fischer et al. 2014) & Human & NMR \\
\hline 5 & $\begin{array}{l}\text { prediction of stroke recurrence after transient ischemic } \\
\text { attack (Jove et al. 2015) }\end{array}$ & Human & LC-MS \\
\hline 6 & prediction of breast cancer risk (Bro et al. 2015) & Human & NMR \\
\hline 7 & $\begin{array}{l}\text { prediction of preeclampsia and gestational hypertension } \\
\text { (Austdal et al. 2015) }\end{array}$ & Human & NMR \\
\hline 8 & prediction of development of obesity (Ni et al. 2015) & Human & LC-MS \\
\hline 9 & $\begin{array}{l}\text { prediction of 1-year outcome in subarachnoid haemorrhage } \\
\text { (Sjoberg et al. 2015) }\end{array}$ & Human & GC-MS \\
\hline 10 & $\begin{array}{l}\text { prediction of survival of lung cancer patients undergoing } \\
\text { treatment (Hao et al. 2016a, b) }\end{array}$ & Human & $\begin{array}{l}\text { GC-MS and } \\
\text { NMR }\end{array}$ \\
\hline 11 & $\begin{array}{l}\text { a predictive metabolic signature for the transition from } \\
\text { gestational diabetes to type } 2 \text { diabetes (Allalou et al. 2016) }\end{array}$ & Human & $\begin{array}{l}\text { GC-MS and } \\
\text { LC-MS }\end{array}$ \\
\hline 12 & $\begin{array}{l}\text { prediction of survival of patients with decompensated } \\
\text { cirrhosis s } 2016 \\
\text { (McPhail et al. 2016) }\end{array}$ & Human & $\begin{array}{l}\text { NMR and LC- } \\
\text { MS }\end{array}$ \\
\hline
\end{tabular}




\begin{tabular}{|l|l|l|l|}
\hline $\mathbf{1 3}$ & $\begin{array}{l}\text { prediction of postoperative hypoxaemia (Maltesen et al. } \\
\text { 2016) }\end{array}$ & Human & NMR \\
\hline $\mathbf{1 4}$ & prediction of ALS clinical progression (Blasco et al. 2018) & Human & LC-MS \\
\hline $\mathbf{1 5}$ & prediction of all-cause death (Deelan and al 2019) & Human & NMR \\
\hline
\end{tabular}

Footnotes:

1) significant studies are highlighted with double asterisks in blue **

2) some studies have several publications associated with them

3) the table is unlikely to be exhaustive due to the different keywords used for some studies

It can be seen from Table 2 that there are 13 studies dealing with the prediction of drug pharmacokinetics, 6 on prediction of drug metabolism, 25 on prediction of drug efficacy, 17 on prediction of adverse events and a further 15 predictive metabonomics studies where the prediction is based on an intervention other than drug administration. Thus we have at least 61 pharmacometabonomics studies in the literature to date. Of these 61 pharmacometabonomics and 15 predictive metabonomics studies, 65 were conducted in humans and 11 in the rat.

The development of pharmacometabonomics has been significant over the past 10 years especially. Several reviews of the field have already appeared, (Burt and Nandal 2016; Everett 2016) so in the remainder of this chapter, we will focus on recent developments in the four key areas of prediction of drug pharmacokinetics, metabolism efficacy and safety.

\section{Prediction of Drug Pharmacokinetics (PK)}

The prediction of drug PK is especially important in situations where the therapeutic index (TI) of a drug is relatively low and also variable. Inappropriately high drug doses may lead to adverse effects in individual patients. The group of Rima Kaddurah-DaouK et al used LC-MS methodologies to measure correlations between baseline plasma lipids of healthy volunteers and the PK of methylphenidate, trade name Ritalin.(Kaddurah-Daouk et al. 2018)

Everett Pharmacometabonomics: Handbook of Experimental Pharmacology 100 Page 21 
<smiles>COC(=O)C(c1ccccc1)C1CCCCN1</smiles>

methylphenidate, Ritalin

The phosphatidylcholine PC(38:5) was negatively correlated with the drug AUC and the blood plasma $\mathrm{C}_{\max }$ values and the ceramide $\operatorname{Cer}(\mathrm{d} 18: 1 / 24: 1)$ was positively correlated with the plasma halflife of the drug metabolite ritalinic acid. Carboxylesterase 1(CES1) metabolises methylphenidate and other drugs such as cocaine and heroin via amide and ester bond hydrolysis. It was suggested that CES1 has a role in lipid metabolism and that the findings could be used for the prediction of the PK not only of methylphenidate, but other drugs metabolised by CES1. (Kaddurah-Daouk et al. 2018)

Differences in cytochrome P450 3A activities are a major source of variability in patient drug responses. Lee et al developed a model for the prediction of CYP3A activity in the presence of inhibitors and inducers that was able to predict the clearance of midazolam with $\mathrm{r}^{2}=0.75$. (Lee et al. 2019) GC and GC-MS methodology was used in a targeted fashion to measure the concentrations of a small number of endogenous steroids in human volunteer urine and plasma samples.



These data were amalgamated together with CYP3A5 genotype information to develop a model for the prediction of midazolam clearance. It was concluded that use of the model could be valuable for predicting CYP3A activities generally in drug development but that further validation was required.

\section{Prediction of Drug Metabolism}

He et al have shown that pre-dose profiling by NMR spectroscopy of volunteer blood plasma could allow prediction of some metabolic and PK characteristics of losartan and its metabolite EXP3174.(He et al. 2018) 
<smiles>CCCCc1nc(Cl)c(CO)n1Cc1ccc(-c2ccccc2-c2nnn[nH]2)cc1</smiles>

losartan<smiles>CCCCc1nc(Cl)c(C(=O)O)n1Cc1ccc(-c2ccccc2-c2nnn[nH]2)cc1</smiles>

carboxylosartan, E3174

Losartan and its bioactive metabolite EXP3174 show a large degree of inter-individual differences in blood plasma concentrations that impact upon efficacy and safety. He et al showed that pre-dose LDL/VLDL, lactate, citrate, creatine and glucose concentrations were positively correlated with, and HDL, creatinine, choline, glycine and phosphorylcholine concentrations were negatively correlated with the ratio of AUCs of EXP3174 and losartan. Pre-dose LDL/VLDL, lactate and glucose concentrations were positively correlated with, and choline, citrate concentrations were negatively correlated with the ratio of $\mathrm{C}_{\max }$ values of EXP3174 and losartan. The switch of citrate from positively correlating with the ratio of AUCs to negatively correlating with the ratio of $\mathrm{C}_{\max }$ values of EXP3174 and losartan was not commented upon. However, as Table 2 in the paper shows that the FDR value for citrate in the pathway analysis was 0.64 i.e. a $>60 \%$ chance of a false discovery, then perhaps that switch is not surprising. Simple formulae involving creatinine and lactate and also choline and glucose were derived for calculating the ratios of the AUCs and the $\mathrm{C}_{\max }$ values of EXP3174 and losartan respectively. (He et al. 2018)

\section{Prediction of Drug Efficacy}

NMR spectroscopy of blood plasma was used to show a discrimination between atrial fibrillation patients on warfarin treatment that had stable versus unstable blood thickness. However, the study 
was not able to demonstrate any such discrimination for patients who were newly treated with warfarin and it was concluded that further studies were required. (Bawadikji et al. 2019)<smiles>CC(=O)CC(c1ccccc1)c1c(O)c2ccccc2oc1=O</smiles>

Park and co-workers used GC-MS analysis of urine metabolites in early-phase type 2 diabetes mellitus (T2DM) patients to show that baseline levels of citrate and hippurate were significantly different for responders and non-responders to metformin treatment. (Park et al. 2018)<smiles>CN(C)C(=N)NC(=N)N</smiles>

The response to treatment was assessed on the basis of changes in glycated haemoglobin A1c (HbAlc) levels from baseline. Pre-dose levels of myo-inositol were also marginally significantly different between these groups. This study was seen to be important in the context of developing personalised medicine, given the significant global burden of T2DM and the variability of patient response to treatment with metformin, a key medicine for treatment of the disease.

\section{Prediction of Drug Safety}

Paclitaxel (brand name Taxol) is a natural product widely used in the treatment of breast cancer. However, its usage is limited by many side effects including the development of peripheral neuropathy, which causes treatment delays or discontinuation in about one quarter of the patients. (Sun et al. 2018) 




paclitaxel, HMDB0015360, (Wishart et al. 2018)

The group of Sun et al used an NMR spectroscopic approach to show that pre-treatment levels of blood histidine, phenylalanine and threonine were inversely associated with maximal change in the peripheral neuropathy index CIPN8. (Sun et al. 2018) This work promises to inform personalised medicine approaches to the selection of patients for treatment who will not suffer peripheral pain side effects.

Colorectal cancer is commonly treated with the topoisomerase I inhibitor, irinotecan.

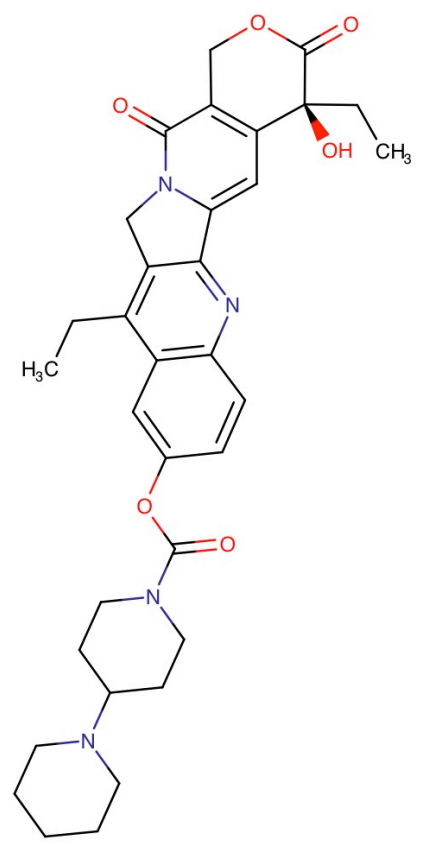

irinotecan (HMDB14900, (Wishart et al. 2018) 
However, several adverse effects are associated with its use, including gastrointestinal toxicity (delayed onset diarrhoea) and myelosuppression. Gao et al used untargeted GC-MS and LC-MS as well as other targeted metabonomics methods to analyse biofluids from rats treated with the drug. (Gao et al. 2019) OPLS-DA analysis of pre-dose serum metabolites showed a significant discrimination between sensitive rats displaying adverse drug side effects and non-sensitive rats. The bile acids cholic acid, deoxycholic acid and glycocholic acid together with phenylalanine were predictors for late-onset diarrhoea. The ketogenic amino acids phenylalanine, lysine and tryptophan were predictive of myelosuppression.(Gao et al. 2019)

\section{Not pharmacometabonomics!}

One issue that readers should be aware of is that many studies purporting to be pharmacometabonomics studies are merely metabonomics studies of the effects of drugs and nothing to do with predicting the effects of drug treatment. This growing confusion in the literature is to be regretted and resisted.(Balashova et al. 2018; Kaddurah-Daouk et al. 2015)

\section{Prediction of Interventions other than Drug Treatment: Predictive Metabonomics}

In the original discovery of pharmacometabonomics, it was envisaged that the methodology would work for interventions other than drug treatment, such as diet changes, physical exercise or even just the passage of time.(Clayton et al. 2006) This type of experiment is termed predictive metabonomics rather than pharmacometabonomics. Indeed, pharmacometabonomics is one member of the broader class of predictive metabonomics experiments, where the intervention is drug treatment. Predictive metabonomics has been defined as 'the prediction of the outcome of an intervention in an individual based on a mathematical model of pre-intervention metabolite signatures' (Everett 2015) We will now illustrate the application of this prognostic methodology with some recent examples (see Table 2 for a fuller listing).

Pulmonary dysfunction resulting in hypoxaemia is a common complication following cardiac surgery. No predictive biomarkers are available to help identify patients that might suffer from this disease, which is characterised by low partial pressure of oxygen in arterial blood $\left(\mathrm{PaO}_{2}\right)$. Maltesen et al used ${ }^{1}$ H NMR spectroscopy to study blood serum taken from the pulmonary artery and left atrium of 47 coronary artery bypass graft patients, 16 hours after weaning off their cardiopulmonary bypass.(Maltesen et al. 2016) At day three post-operation, 32 patients had developed hypoxaemia. It 
was found that levels of carnitine, arachidonic and eicosapentaenoic acid, glycoprotein, citrate, phenylalanine, glycine, plasmalogen, and lysophosphocholine (Lyso-PC) were the most significant in the prediction of day 3 hypoxaemia from day 1 serum analysis. The concentrations of several of these metabolites were found to be individually correlated to day $3, \mathrm{PaO}_{2}$ levels. Thus predictive metabonomics methods are capable of prognosing later adverse effects of surgery well before any clinical sign. The results are promising in terms of targeting further treatments to affected patients and also directing research for new drugs to treat this disease on the basis of the perturbed metabolic pathways discovered.

Estimating mortality risk in ageing patients is important for decisions on treatment options. Current methods of mortality prediction are limited and some of the parameters, including systolic blood pressure and total cholesterol show opposite trends in the elderly compared with middle-aged people.(Deelan and al 2019) A predictive method based on metabolite profiles would find great clinical utility. Fischer and co-workers used ${ }^{1} \mathrm{H}$ NMR spectroscopy of the plasma of 9,842 individuals (randomly sampled from the Estonian Biobank) to elucidate that albumin, glycoprotein acetyls, citrate and the mean diameter of VLDL particles are associated with all-cause and causespecific (cardiovascular and cancer) mortality.(Fischer et al. 2014) The group of Deelan et al recently published the results of a much larger study of 44,168 individuals, 5,512 of who died during follow-up, using ${ }^{1} \mathrm{H}$ NMR spectroscopy of EDTA plasma and serum. (Deelan and al 2019) A set of 14 metabolic biomarkers was found to independently associate with all-cause mortality. A mortality score based on gender and these 14 biomarkers led to an improved risk prediction compared to the conventional risk score. The biomarkers included albumin, glycoprotein acetyls and mean diameter of VLDL particles, as found by Fischer, but also included acetoacetate, glucose and a number of amino acids. It was concluded that predictive metabonomics methods could be used in the future to guide patient care, if further validated in other clinical settings.(Deelan and al 2019)

\section{Conclusions}

Metabonomics and predictive metabonomics, including pharmacometabonomics, are starting to have an impact on biomedical and medical research, and in the future it is expected that these technologies will be widely used for both diagnostic and prognostic applications in real clinical settings.

Metabolic profiling will be used synergistically with genomic analyses to assist in the delivery of personalised medicine. The approach of metabolite profiling, as opposed to genetic analysis, benefits hugely from the fact that it is a systems biology approach that integrates both genetic and 
environmental information and gives insights into the real-time status of a subject, as opposed to information on genetic risk factors that may not develop into a disease phenotype. In this context it is encouraging to see the work done by the groups of Kaddurah-Daouk and Weinshilboum on the development of pharmacometabonomics-led pharmacogenomics. (Ji et al. 2011; Neavin et al. 2016) The advent of large biobanks and the development of phenome centres such as those in London, Singapore and Birmingham, amongst others, gives the opportunity for very large-scale clinical studies that will undoubtedly lead to new insights into patient treatments in many disease areas. The great stability and automation capabilities of NMR spectroscopy as a metabolite detection technology are well matched to the task of analysing these huge numbers of samples, as was seen above in the work of Deelan and co-workers on all-cause mortality prediction.(Deelan and al 2019) One major area that still needs much attention is metabolite identification. This is a significant challenge for both NMR- and MS-based technologies and in spite of the many advances in both areas in recent years, it is still the fact that most metabolites detected in most untargeted metabonomics experiments are unidentified. Progress on this issue promises to enable much more comprehensive biochemical insights into complex organisms including humans and their diseases. The future for the use of metabolic profiling in clinical pharmacology and medicine in general is very bright.

\section{Acknowledgements}

I would like to acknowledge productive and enjoyable collaborations with Professor Jeremy Nicholson, Professor John Lindon, Professor Ian Wilson, Professor Elaine Holmes and Professor Elizabeth Shephard over the past 35 years or more. I have gained very much from these stimulating interactions. 


\section{Glossary}

\begin{tabular}{|c|c|}
\hline term & meaning \\
\hline $\begin{array}{l}\text { area under the curve } \\
\text { (AUC) }\end{array}$ & $\begin{array}{l}\text { the integral over time of the concentration of a drug in blood } \\
\text { plasma: a measure of the exposure of a patient to the drug }\end{array}$ \\
\hline $\begin{array}{l}\text { capillary electrophoresis } \\
\text { (CE) }\end{array}$ & $\begin{array}{l}\text { an electrophoretic separation methodology based on } \\
\text { molecular charge and mobility that can be hyphenated to mass } \\
\text { spectrometry }\end{array}$ \\
\hline $\mathbf{C}_{\max }$ & the maximal blood plasma concentration achieved by a drug \\
\hline diagnosis & $\begin{array}{l}\text { the characterisation of an organism, disease state, phenotype } \\
\text { or response to an intervention }\end{array}$ \\
\hline exposome & $\begin{array}{l}\text { the cumulative array of exogenous chemicals present in the } \\
\text { environment of an organism such as a human, from the womb } \\
\text { to death, that can interact with and influence that organism's } \\
\text { metabolism and physiology }\end{array}$ \\
\hline FDR, false discovery rate & $\begin{array}{l}\text { a parameter used in multivariate statistical analysis to show } \\
\text { the probability of a false discovery via making multiple } \\
\text { comparisons e.g. FDR }=0.1 \text { means up to } 10 \% \text { of metabolites } \\
\text { discovered as statistically significantly discriminating will } \\
\text { actually be false discoveries: the normal p value is inadequate } \\
\text { to cover for this }\end{array}$ \\
\hline GC & $\begin{array}{l}\text { gas chromatography: a powerful method for the separation of } \\
\text { volatile compounds. For use in metabonomics, pre- } \\
\text { derivatisation of metabolites is required in order to achieve } \\
\text { volatility }\end{array}$ \\
\hline HDL & high density lipoprotein \\
\hline HPLC & $\begin{array}{l}\text { high performance liquid chromatography: a powerful } \\
\text { analytical separation technology often hyphenated with mass } \\
\text { spectrometry }\end{array}$ \\
\hline LDL & low density lipoprotein \\
\hline metabolic entropy & $\begin{array}{l}\text { the degree of disorder of metabolite concentrations in an } \\
\text { individual or in a group of subjects }\end{array}$ \\
\hline metabolic phenotype & $\begin{array}{l}\text { multicomponent metabolic characteristics that result from the } \\
\text { cumulative interactions of genetic variation, gene products } \\
\text { and environmental exposures and that can be related directly } \\
\text { to disease risks and therapeutic responses: also known as the } \\
\text { metabotype }\end{array}$ \\
\hline metabolic trajectory & $\begin{array}{l}\text { the changes in metabolite concentrations over time in } \\
\text { response to an intervention }\end{array}$ \\
\hline metabolite & $\begin{array}{l}\text { a compound in a biological matrix of an organism that is } \\
\text { produced in that organism by an enzymatic pathway }\end{array}$ \\
\hline
\end{tabular}

Everett Pharmacometabonomics: Handbook of Experimental Pharmacology 100 Page 29 


\begin{tabular}{|c|c|}
\hline metabolomics & $\begin{array}{l}\text { metabolic profiling defined in an observational fashion as 'a } \\
\text { comprehensive analysis in which all the metabolites of a } \\
\text { biological system are identified and quantified' }\end{array}$ \\
\hline metabolome & $\begin{array}{l}\text { the full set of metabolites within, or that can be secreted from, } \\
\text { a biological system such as a cell type or tissue }\end{array}$ \\
\hline metabonome & $\begin{array}{l}\text { the full set of metabolites contained within an organism i.e. } \\
\text { the sum of all the metabolomes }\end{array}$ \\
\hline metabonomics & $\begin{array}{l}\text { metabolic profiling defined in an experimental fashion as 'the } \\
\text { quantitative measurement of the multiparametric metabolic } \\
\text { response of living systems to pathophysiological stimuli or } \\
\text { genetic modification' }\end{array}$ \\
\hline metabotype & $\begin{array}{l}\text { a probabilistic, multiparametric description of an organism in } \\
\text { a given physiological state based on analysis of its cell types, } \\
\text { biofluids and tissues: see metabolic phenotype }\end{array}$ \\
\hline microbiome & $\begin{array}{l}\text { the collection of microorganisms present both in and on an } \\
\text { organism, in a variety of environmental niches }\end{array}$ \\
\hline MS & $\begin{array}{l}\text { mass spectrometry: a sensitive analytical methodology for the } \\
\text { detection and characterisation of metabolites in biological } \\
\text { matrices }\end{array}$ \\
\hline $\begin{array}{l}\text { multivariate analysis: } \\
\text { MVA }\end{array}$ & $\begin{array}{l}\text { multivariate (statistical) analysis: a method for the analysis of } \\
\text { multiple variables in an experiment or observation at a time } \\
\text { and the simplification of the analysis problem by reduction of } \\
\text { the large number of initial variables to a small number of key } \\
\text { factors }\end{array}$ \\
\hline NMR spectroscopy & $\begin{array}{l}\text { nuclear magnetic resonance spectroscopy: the most powerful } \\
\text { method for molecular structure identification in solution, } \\
\text { including metabolites in biological fluids }\end{array}$ \\
\hline OPLS-DA & $\begin{array}{l}\text { orthogonal projection to latent structures with discriminant } \\
\text { analysis: a supervised (and therefore potentially biased) } \\
\text { approach to multivariate data analysis with the aim of finding } \\
\text { metabolites that are statistically significantly discriminating } \\
\text { between two groups e.g. responders and non-responders, and } \\
\text { which also discards metabolite variations that are orthogonal } \\
\text { to the group discrimination }\end{array}$ \\
\hline panomics & $\begin{array}{l}\text { the strategy of understanding a biological system, such as a } \\
\text { disease state, by a combined use of e.g. genomics, } \\
\text { transcriptomics, proteomics and metabonomics, so as to } \\
\text { obtain much more information than from studying the system } \\
\text { with a single technology }\end{array}$ \\
\hline personalised medicine & $\begin{array}{l}\text { the use of genomic, molecular and clinical information to } \\
\text { select treatments or medicines that are more likely to be both } \\
\text { effective and safe for that patient: also known as precision } \\
\text { medicine or stratified medicine }\end{array}$ \\
\hline
\end{tabular}

Everett Pharmacometabonomics: Handbook of Experimental Pharmacology 100 Page 30 


\begin{tabular}{|c|c|}
\hline pharmacogenomics & $\begin{array}{l}\text { the prediction of the effects of a drug on the basis of } \\
\text { individual genetic profiles }\end{array}$ \\
\hline pharmacokinetics (PK) & $\begin{array}{l}\text { the measurement of the time course of the absorption, } \\
\text { distribution, metabolism and excretion of a drug }\end{array}$ \\
\hline pharmacometabolomics & $\begin{array}{l}\text { this term is used synonymously with pharmacometabonomics } \\
\text { (see below), but is sometimes erroneously used to describe } \\
\text { the investigation of the effects of a drug on an organism: this } \\
\text { is just diagnostic metabonomics }\end{array}$ \\
\hline pharmacometabonomics & $\begin{array}{l}\text { the prediction of the effects of a drug on the basis of a } \\
\text { mathematical model of pre-dose metabolite profiles }\end{array}$ \\
\hline phenotype & $\begin{array}{l}\text { the quantitative or qualitative measurement of specific } \\
\text { parameters or traits that characterise individual functional } \\
\text { biological classes or groups }\end{array}$ \\
\hline $\begin{array}{l}\text { predictive metabolic } \\
\text { phenotyping or predictive } \\
\text { metabonomics }\end{array}$ & $\begin{array}{l}\text { the prediction of the outcome of an intervention in an } \\
\text { individual based on a mathematical model of pre-intervention } \\
\text { metabolite profiles. The intervention could be a change in } \\
\text { diet, exercise, the passage of time, surgical treatment etc. } \\
\text { Pharmacometabonomics is one case of predictive } \\
\text { metabonomics, which covers the prognosis of any } \\
\text { intervention }\end{array}$ \\
\hline $\begin{array}{l}\text { principal components } \\
\text { analysis (PCA) }\end{array}$ & $\begin{array}{l}\text { an unsupervised (and therefore unbiased) multivariate } \\
\text { statistical method for analysing high dimensional data, such } \\
\text { as spectral data from metabonomics experiments. The PCA } \\
\text { effects a drastic dimensionality reduction and transformation } \\
\text { so that new principal components readily display the variance } \\
\text { present in the dataset and therefore patterns in the data like } \\
\text { clusters or groupings can be readily discerned and outliers } \\
\text { identified }\end{array}$ \\
\hline prognosis & $\begin{array}{l}\text { the prediction of disease onset, disease outcome or the } \\
\text { outcome of an intervention such as drug treatment }\end{array}$ \\
\hline T2DM & type 2 diabetes mellitus \\
\hline therapeutic index (TI) & $\begin{array}{l}\text { the TI measures the the ratio of the effective dose of a drug } \\
\text { for } 50 \% \text { of patients (expressed as } \mathrm{ED}_{50} \text { ) to the toxic dose } \\
\text { expressed as the } \mathrm{TD}_{50} \text {. Usually a minimal TI of } 10 \text { is required } \\
\text { in drug development: some companies will aim for a more } \\
\text { conservative TI of } 30\end{array}$ \\
\hline UPLC & $\begin{array}{l}\text { ultra-performance liquid chromatography: a more efficient } \\
\text { and effective form of HPLC using smaller column packings } \\
\text { and higher pressures }\end{array}$ \\
\hline VLDL & very low density lipoprotein \\
\hline
\end{tabular}

Everett Pharmacometabonomics: Handbook of Experimental Pharmacology 100 Page 31 


\section{References}

Abo R, Hebbring S, Ji Y, Zhu H, Zeng ZB, Batzler A, Jenkins GD, Biernacka J, Snyder K, Drews M, Fiehn O, Fridley B, Schaid D, Kamatani N, Nakamura Y, Kubo M, Mushiroda T, Kaddurah-Daouk R, Mrazek DA, Weinshilboum RM (2012) Merging pharmacometabolomics with pharmacogenomics using '1000 Genomes' single-nucleotide polymorphism imputation: selective serotonin reuptake inhibitor response pharmacogenomics. Pharmacogenet Genomics 22: 247-53. doi: 10.1097/FPC.0b013e32835001c9

Alejandro Vargas D, Dario Prieto M, Jose Martinez-Valencia A, Cossio A, Burgess KEV, Burchmore RJS, Adelaida Gomez M (2019) Pharmacometabolomics of Meglumine Antimoniate in Patients With Cutaneous Leishmaniasis. Frontiers in Pharmacology 10. doi: 10.3389/fphar.2019.00657

Allalou A, Nalla A, Prentice KJ, Liu Y, Zhang M, Dai FF, Ning X, Osborne LR, Cox BJ, Gunderson EP, Wheeler MB (2016) A Predictive Metabolic Signature for the Transition From Gestational Diabetes Mellitus to Type 2 Diabetes. Diabetes 65: 2529-2539. doi: 10.2337/db15-1720

Amin AM, Chin LS, Teh C-H, Mostafa H, Noor DAM, Kader MASKA, Hay YK, Ibrahim B (2018) Pharmacometabolomics analysis of plasma to phenotype clopidogrel high on treatment platelets reactivity in coronary artery disease patients. European Journal of Pharmaceutical Sciences 117: 351-361. doi: 10.1016/j.ejps.2018.03.011

Amin AM, Chin LS, Teh CH, Mostafa H, Noor DAM, Kader M, Hay YK, Ibrahim B (2017) H-1 NMR based pharmacometabolomics analysis of urine identifies metabolic phenotype of clopidogrel high on treatment platelets reactivity in coronary artery disease patients. Journal of Pharmaceutical and Biomedical Analysis 146: 135-146. doi: 10.1016/j.jpba.2017.08.018

Andersson U, Lindberg J, Wang S, Balasubramanian R, Marcusson-Stahl M, Hannula M, Zeng C, Juhasz PJ, Kolmert J, Backstrom J, Nord L, Nilsson K, Martin S, Glinghammar B, Cederbrant K, SchuppeKoistinen I (2009) A systems biology approach to understanding elevated serum alanine transaminase levels in a clinical trial with ximelagatran. Biomarkers 14: 572-586. doi: $10.3109 / 13547500903261354$

Austdal M, Tangeras LH, Skrastad RB, Salvesen KA, Austgulen R, Iversen A-C, Bathen TF (2015) First Trimester Urine and Serum Metabolomics for Prediction of Preeclampsia and Gestational Hypertension: A Prospective Screening Study. International Journal of Molecular Sciences 16: 21520-21538. doi: 10.3390/ijms160921520

Backshall A, Sharma R, Clarke SJ, Keun HC (2011) Pharmacometabonomic profiling as a predictor of toxicity in patients with inoperable colorectal cancer treated with capecitabine. Clin Cancer Res 17: 3019-28. doi: 10.1158/1078-0432.ccr-10-2474

Balashova EE, Maslov DL, Lokhov PG (2018) A Metabolomics Approach to Pharmacotherapy Personalization. Journal of Personalized Medicine 8. doi: 10.3390/jpm8030028

Bawadikji AA, Teh C-H, Sheikh Abdul Kader MAB, Abdul Wahab MJB, Syed Sulaiman SA, Ibrahim B (2019) Plasma Metabolites as Predictors of Warfarin Outcome in Atrial Fibrillation. American journal of cardiovascular drugs : drugs, devices, and other interventions. doi: 10.1007/s40256019-00364-2

Beckonert O, Keun HC, Ebbels TMD, Bundy JG, Holmes E, Lindon JC, Nicholson JK (2007) Metabolic profiling, metabolomic and metabonomic procedures for NMR spectroscopy of urine, plasma, serum and tissue extracts. Nature Protocols 2: 2692-2703. doi: 10.1038/nprot.2007.376

Bharti SK, Roy R (2012) Quantitative H-1 NMR spectroscopy. Trac-Trends in Analytical Chemistry 35: 526. doi: 10.1016/j.trac.2012.02.007

Blasco H, Patin F, Descat A, Garcon G, Corcia P, Gele P, Lenglet T, Bede P, Meininger V, Devos D, Gossens JF, Pradat P-F (2018) A pharmaco-metabolomics approach in a clinical trial of ALS: Identification of predictive markers of progression. Plos One 13. doi: 10.1371/journal.pone.0198116

Bro R, Kamstrup-Nielsen MH, Engelsen SB, Savorani F, Rasmussen MA, Hansen L, Olsen A, Tjonneland A, Dragsted LO (2015) Forecasting individual breast cancer risk using plasma metabolomics and biocontours. Metabolomics 11: 1376-1380. doi: 10.1007/s11306-015-0793-8

Broadhurst DI, Kell DB (2006) Statistical strategies for avoiding false discoveries in metabolomics and related experiments. Metabolomics 2: 171-196. doi: 10.1007/s11306-006-0037-z 
Burt T, Nandal S (2016) Pharmacometabolomics in Early-Phase Clinical Development. Cts-Clinical and Translational Science 9: 128-138. doi: 10.1111/cts.12396

Cao Z, Miller MS, Lubet RA, Grubbs CJ, Beger RD (2019) Pharmacometabolomic Pathway Response of Effective Anticancer Agents on Different Diets in Rats with Induced Mammary Tumors. Metabolites 9. doi: 10.3390/metabo9070149

Chen YH, Xu J, Zhang RP, Abliz Z (2016) Methods used to increase the comprehensive coverage of urinary and plasma metabolomes by MS. Bioanalysis 8: 981-997. doi: 10.4155/bio-2015-0010

Clayton T, Lindon J, Cloarec O, Antti H, Charuel C, Hanton G, Provost J, Le Net J, Baker D, Walley R, Everett J, Nicholson J (2006) Pharmaco-metabonomic phenotyping and personalized drug treatment. Nature 440: 1073-1077. doi: 10.1038/nature04648

Clayton TA, Baker D, Lindon JC, Everett JR, Nicholson JK (2009) Pharmacometabonomic identification of a significant host-microbiome metabolic interaction affecting human drug metabolism. Proceedings of the National Academy of Sciences of the United States of America 106: 1472814733. doi: $10.1073 /$ pnas.0904489106

Coen M, Goldfain-Blanc F, Rolland-Valognes G, Walther B, Robertson DG, Holmes E, Lindon JC, Nicholson JK (2012) Pharmacometabonomic investigation of dynamic metabolic phenotypes associated with variability in response to galactosamine hepatotoxicity. J Proteome Res 11: 2427-40. doi: $10.1021 /$ pr201161f

Condray R, Dougherty GG, Keshavan MS, Reddy RD, Haas GL, Montrose DM, Matson WR, McEvoy J, Kaddurah-Daouk R, Yao JK (2011) 3-Hydroxykynurenine and clinical symptoms in first-episode neuroleptic-naive patients with schizophrenia. International Journal of Neuropsychopharmacology 14: 756-767. doi: 10.1017/s1461145710001689

Cunningham K, Claus SP, Lindon JC, Holmes E, Everett JR, Nicholson JK, Coen M (2012) Pharmacometabonomic Characterization of Xenobiotic and Endogenous Metabolic Phenotypes That Account for Inter-individual Variation in Isoniazid-Induced Toxicological Response. J Proteome Res 11: 4630-42. doi: 10.1021/pr300430u

Dai D, Tian Y, Guo H, Zhang P, Huang Y, Zhang W, Xu F, Zhang Z (2016) A pharmacometabonomic approach using predose serum metabolite profiles reveals differences in lipid metabolism in survival and non-survival rats treated with lipopolysaccharide. Metabolomics 12. doi: 10.1007/s11306-015-0892-6

de Oliveira FA, Shahin MH, Gong Y, McDonough CW, Beitelshees AL, Gums JG, Chapman AB, Boerwinkle E, Turner ST, Frye RF, Fiehn O, Kaddurah-Daouk R, Johnson JA, Cooper-DeHoff RM (2016) Novel plasma biomarker of atenolol-induced hyperglycemia identified through a metabolomicsgenomics integrative approach. Metabolomics 12. doi: 10.1007/s11306-016-1076-8

Deelan J, al e (2019) A metabolic profile of all-cause mortality risk identified in an observational study of 44,168 individuals. Nature Communications 10:3346: 1-8. doi: 10.1038/s41467-019-113119

Dona AC, Kyriakides M, Scott F, Shephard EA, Varshavi D, Veselkov K, Everett JR (2016) A guide to the identification of metabolites in NMR-based metabonomics/metabolomics experiments. Computational and Structural Biotechnology Journal 14: 135-153. doi: http://dx.doi.org/10.1016/j.csbj.2016.02.005

Dong B, Jia J, Hu W, Chen Q, Jiang C, Pan J, Huang Y, Xue W, Gao H (2013) Application of H-1 NMR metabonomics in predicting renal function recoverability after the relief of obstructive uropathy in adult patients. Clinical Biochemistry 46: 346-353. doi: 10.1016/j.clinbiochem.2012.11.012

Ed. Lindon J, Nicholson, JK and Holmes E (2019) The handbook of metabolic phenotyping. Elsevier, Oxford

Ellero-Simatos S, Lewis JP, Georgiades A, Yerges-Armstrong LM, Beitelshees AL, Horenstein RB, Dane A, Harms AC, Ramaker R, Vreeken RJ, Perry CG, Zhu H, Sanchez CL, Kuhn C, Ortel TL, Shuldiner AR, Hankemeier T, Kaddurah-Daouk R (2014) Pharmacometabolomics reveals that serotonin is implicated in aspirin response variability. CPT: pharmacometrics \& systems pharmacology 3 : e125-e125. doi: 10.1038/psp.2014.22

Emwas A-H, Luchinat C, Turano P, Tenori L, Roy R, Salek RM, Ryan D, Merzaban JS, Kaddurah-Daouk R, Zeri AC, Gowda GAN, Raftery D, Wang Y, Brennan L, Wishart DS (2015) Standardizing the experimental conditions for using urine in NMR-based metabolomic studies with a particular 
focus on diagnostic studies: a review. Metabolomics 11: 872-894. doi: 10.1007/s11306-0140746-7

Evans CR, Karnovsky A, Puskarich MA, Michailidis G, Jones AE, Stringer KA (2019) Untargeted Metabolomics Differentiates L-Carnitine Treated Septic Shock 1-Year Survivors and Nonsurvivors. Journal of Proteome Research 18: 2004-2011. doi:

10.1021/acs.jproteome.8b00774

Everett JR (2015) Pharmacometabonomics in humans: a new tool for personalized medicine. Pharmacogenomics 16: 737-754. doi: 10.2217/pgs.15.20

Everett JR (2016) From Metabonomics to Pharmacometabonomics: The Role of Metabolic Profiling in Personalized Medicine. Frontiers in Pharmacology 7: 15. doi: 10.3389/fphar.2016.00297

Everett JR, Holmes E, Veselkov KA, Lindon JC, Nicholson JK (2019) A unified conceptual framework for metabolic phenotyping in diagnosis and prognosis. Trends in Pharmacological Sciences in press. doi: 10.1016/j.tips.2019.08.004

Everett JR, Lindon JC, Nicholson JK (2016) Pharmacometabonomics and Predictive Metabonomics: New Tools for Personalized Medicine. In: Holmes E, Jeremy K, Darzi AW, Lindon JC (eds) Metabolic Phenotyping in Personalized and Public Healthcare. Academic Press, London, pp 138-165

Everett JR, Loo RL, Pullen FS (2013) Pharmacometabonomics and personalized medicine. Annals of Clinical Biochemistry 50: 523-545. doi: 10.1177/0004563213497929

Fiehn O (2002) Metabolomics--the link between genotypes and phenotypes. Plant Mol Biol 48: 155-71.

Fischer K, Kettunen J, Wurtz P, Haller T, Havulinna AS, Kangas AJ, Soininen P, Esko T, Tammesoo M-L, Maegi R, Smit S, Palotie A, Ripatti S, Salomaa V, Ala-Korpela M, Perola M, Metspalu A (2014) Biomarker Profiling by Nuclear Magnetic Resonance Spectroscopy for the Prediction of AllCause Mortality: An Observational Study of 17,345 Persons. Plos Medicine 11. doi: 10.1371/journal.pmed.1001606

Gamage N, Barnett A, Hempel N, Duggleby RG, Windmill KF, Martin JL, McManus ME (2006) Human sulfotransferases and their role in chemical metabolism. Toxicological Sciences 90: 5-22. doi: $10.1093 /$ toxsci/kfj061

Gao Y, Li W, Chen J, Wang X, Lv Y, Huang Y, Zhang Z, Xu F (2019) Pharmacometabolomic prediction of individual differences of gastrointestinal toxicity complicating myelosuppression in rats induced by irinotecan. Acta Pharmaceutica Sinica B 9: 157-166. doi: 10.1016/j.apsb.2018.09.006

Gowda GAN, Raftery D (2017) Recent Advances in NMR-Based Metabolomics. Analytical Chemistry 89: 490-510. doi: 10.1021/acs.analchem.6b04420

Gupta M, Neavin D, Liu D, Biernacka J, Hall-Flavin D, Bobo WV, Frye MA, Skime M, Jenkins GD, Batzler A, Kalari K, Matson W, Bhasin SS, Zhu H, Mushiroda T, Nakamura Y, Kubo M, Wang L, KaddurahDaouk R, Weinshilboum RM (2016) TSPAN5, ERICH3 and selective serotonin reuptake inhibitors in major depressive disorder: pharmacometabolomics-informed pharmacogenomics. Molecular Psychiatry 21: 1717-1725. doi: 10.1038/mp.2016.6

Hao D, Sarfaraz MO, Farshidfar F, Bebb DG, Lee CY, Card CM, David M, Weljie AM (2016a) Temporal characterization of serum metabolite signatures in lung cancer patients undergoing treatment. Metabolomics 12. doi: 10.1007/s11306-016-0961-5

Hao D, Sarfaraz MO, Farshidfar F, Bebb DG, Lee CY, Card CM, David M, Weljie AM (2016b) Temporal characterization of serum metabolite signatures in lung cancer patients undergoing treatment (vol 12, 58, 2016). Metabolomics 12. doi: 10.1007/s11306-016-1068-8

He C, Liu Y, Wang Y, Tang J, Tan Z, Li X, Chen Y, Huang Y, Chen X, Ouyang D, Zhou H, Peng J (2018) H-1 NMR based pharmacometabolomics analysis of metabolic phenotype on predicting metabolism characteristics of losartan in healthy volunteers. Journal of Chromatography B-Analytical Technologies in the Biomedical and Life Sciences 1095: 15-23. doi: 10.1016/j.jchromb.2018.07.016

Huang Q, Aa J, Jia H, Xin X, Tao C, Liu L, Zou B, Song Q, Shi J, Cao B, Yong Y, Wang G, Zhou G (2015) A Pharmacometabonomic Approach To Predicting Metabolic Phenotypes and Pharmacokinetic Parameters of Atorvastatin in Healthy Volunteers. Journal of proteome research 14: 3970-81. doi: 10.1021/acs.jproteome.5b00440 
Ji Y, Hebbring S, Zhu H, Jenkins GD, Biernacka J, Snyder K, Drews M, Fiehn O, Zeng Z, Schaid D, Mrazek DA, Kaddurah-Daouk R, Weinshilboum RM (2011) Glycine and a glycine dehydrogenase (GLDC) SNP as citalopram/escitalopram response biomarkers in depression: pharmacometabolomicsinformed pharmacogenomics. Clin Pharmacol Ther 89: 97-104. doi: 10.1038/clpt.2010.250

Jiang L, Lee SC, Ng TC (2018) Pharmacometabonomics analysis reveals serum formate and acetate potentially associated with varying response to gemcitabine-carboplatin chemotherapy in metastatic breast cancer patients. J Proteome Res. doi: 10.1021/acs.jproteome.7b00859

Jove M, Mauri-Capdevila G, Suarez I, Cambray S, Sanahuja J, Quilez A, Farre J, Benabdelhak I, Pamplona R, Portero-Otin M, Purroy F (2015) Metabolomics predicts stroke recurrence after transient ischemic attack. Neurology 84: 36-45.

Kaddurah-Daouk R, Baillie RA, Zhu HJ, Zeng ZB, Wiest MM, Nguyen UT, Watkins SM, Krauss RM (2010) Lipidomic analysis of variation in response to simvastatin in the Cholesterol and Pharmacogenetics Study. Metabolomics 6: 191-201. doi: 10.1007/s11306-010-0207-x

Kaddurah-Daouk R, Bogdanov MB, Wikoff WR, Zhu H, Boyle SH, Churchill E, Wang Z, Rush AJ, Krishnan RR, Pickering E, Delnomdedieu M, Fiehn O (2013) Pharmacometabolomic mapping of early biochemical changes induced by sertraline and placebo. Transl Psychiatry 3: e223. doi: 10.1038/tp.2012.142

Kaddurah-Daouk R, Boyle SH, Matson W, Sharma S, Matson S, Zhu H, Bogdanov MB, Churchill E, Krishnan RR, Rush AJ, Pickering E, Delnomdedieu M (2011) Pretreatment metabotype as a predictor of response to sertraline or placebo in depressed outpatients: a proof of concept. Transl Psychiatry 1: 1-7. doi: 10.1038/tp.2011.22

Kaddurah-Daouk R, Hankemeier T, Scholl EH, Baillie R, Harms A, Stage C, Dalhoff KP, Jurgens G, Taboureau O, Nzabonimpa GS, Motsinger-Reif AA, Thomsen R, Linnet K, Rasmussen HB, Consortium I, Pharmacometabolomics Res N (2018) Pharmacometabolomics Informs About Pharmacokinetic Profile of Methylphenidate. Cpt-Pharmacometrics \& Systems Pharmacology 7: 525-533. doi: 10.1002/psp4.12309

Kaddurah-Daouk R, Weinshilboum R, Pharmacometabolomics Res N (2015) Metabolomic Signatures for Drug Response Phenotypes: Pharmacometabolomics Enables Precision Medicine. Clinical Pharmacology \& Therapeutics 98: 71-75. doi: 10.1002/cpt.134

Kapoor SR, Filer A, Fitzpatrick MA, Fisher BA, Taylor PC, Buckley CD, McInnes IB, Raza K, Young SP (2013) Metabolic Profiling Predicts Response to Anti-Tumor Necrosis Factor alpha Therapy in Patients With Rheumatoid Arthritis. Arthritis and Rheumatism 65: 1448-1456. doi: 10.1002/art.37921

Karas-Kuzelicki N, Smid A, Tamm R, Metspalu A, Mlinaric-Rascan I (2014) From pharmacogenetics to pharmacometabolomics: SAM modulates TPMT activity. Pharmacogenomics 15: 1437-49. doi: $10.2217 /$ pgs.14.84

Keun HC, Sidhu J, Pchejetski D, Lewis JS, Marconell H, Patterson M, Bloom SR, Amber V, Coombes RC, Stebbing J (2009) Serum Molecular Signatures of Weight Change during Early Breast Cancer Chemotherapy. Clinical Cancer Research 15: 6716-6723. doi: 10.1158/1078-0432.ccr-09-1452

Kienana M, Benz-de Bretagne I, Nadal-Desbarats L, Blasco H, Gyan E, Choquet S, Montigny F, Emond P, Barin-Le Guellec C (2016) Endogenous metabolites that are substrates of Organic Anion Transporter's (OATs) predict methotrexate clearance Pharmacological Research http://dx.doi.org/10.1016/j.phrs.2016.05.021. doi: http://dx.doi.org/10.1016/j.phrs.2016.05.021

Kim B, Lee JW, Hong KT, Yu KS, Jang IJ, Park KD, Shin HY, Ahn HS, Cho JY, Kang HJ (2017) Pharmacometabolomics for predicting variable busulfan exposure in paediatric haematopoietic stem cell transplantation patients. Scientific Reports 7. doi: 10.1038/s41598-017-01861-7

Kind T, Fiehn $O$ (2010) Advances in structure elucidation of small molecules using mass spectrometry. Bioanal Rev 2: 23-60. doi: 10.1007/s12566-010-0015-9

Kwon HN, Kim M, Wen H, Kang S, Yang H-j, Choi M-J, Lee HS, Choi D, Park IS, Suh YJ, Hong S-S, Park S (2011) Predicting idiopathic toxicity of cisplatin by a pharmacometabonomic approach. Kidney International 79: 529-537. doi: 10.1038/ki.2010.440 
Lazarou J, Pomeranz BH, Corey PN (1998) Incidence of adverse drug reactions in hospitalized patients A meta-analysis of prospective studies. Jama-Journal of the American Medical Association 279: 1200-1205. doi: 10.1001/jama.279.15.1200

Lee J, Yoon SH, Yi S, Kim AH, Kim B, Lee S, Yu K-S, Jang I-J, Cho J-Y (2019) Quantitative prediction of hepatic CYP3A activity using endogenous markers in healthy subjects after administration of CYP3A inhibitors or inducers. Drug Metabolism and Pharmacokinetics 34: 247-252. doi: 10.1016/j.dmpk.2019.04.002

Lee JW, Aminkeng F, Bhavsar AP, Shaw K, Carleton BC, Hayden MR, Ross CJD (2014) The emerging era of pharmacogenomics: current successes, future potential, and challenges. Clinical Genetics 86: 21-28. doi: 10.1111/cge.12392

Lewis JP, Yerges-Armstrong LM, Ellero-Simatos S, Georgiades A, Kaddurah-Daouk R, Hankemeier T (2013) Integration of Pharmacometabolomic and Pharmacogenomic Approaches Reveals Novel Insights Into Antiplatelet Therapy. Clinical Pharmacology \& Therapeutics 94: 570-573. doi: 10.1038/clpt.2013.153

Li H, Ni Y, Su M, Qiu Y, Zhou M, Qiu M, Zhao A, Zhao L, Jia W (2007) Pharmacometabonomic phenotyping reveals different responses to xenobiotic intervention in rats. J Proteome Res 6: 1364-70. doi: $10.1021 /$ pr060513q

Lin YS, Kerr SJ, Randolph T, Shireman LM, Senn T, McCune JS (2016) Prediction of intravenous busulfan clearance by endogenous plasma biomarkers using global pharmacometabolomics. Metabolomics 12. doi: 10.1007/s11306-016-1106-6

Lindon J, Nicholson J, Holmes E, Everett J (2000) Metabonomics: Metabolic processes studied by NMR spectroscopy of biofluids. Concepts in Magnetic Resonance 12: 289-320. doi: 10.1002/10990534(2000)12:5<289::AID-CMR3>3.0.CO;2-W

Lindon JC, Nicholson JK, Holmes E (2007) The handbook of metabonomics and metabolomics. Elsevier, Amsterdam ; Oxford

Lindon JC, Wilson ID (2016) The Development of Metabolic Phenotyping - A Historical Perspective. In: Holmes E, Nicholson JK, Darzi A, Lindon JC (eds) Metabolic phenotyping in personalized and public healthcare. Elsevier, pp 17-48

Liu L, Cao B, Aa J, Zheng T, Shi J, Li M, Wang X, Zhao C, Xiao W, Yu X, Sun R, Gu R, Zhou J, Wu L, Hao G, Zhu X, Wang G (2012) Prediction of the Pharmacokinetic Parameters of Triptolide in Rats Based on Endogenous Molecules in Pre-Dose Baseline Serum. Plos One 7: e43389. doi: 10.1371/journal.pone.0043389

Maltesen RG, Hanifa MA, Kucheryavskiy S, Pedersen S, Kristensen SR, Rasmussen BS, Wimmer R (2016) Predictive biomarkers and metabolic hallmark of postoperative hypoxaemia. Metabolomics 12. doi: $10.1007 / \mathrm{s} 11306-016-1018-5$

Markley JL, Brüschweiler R, Edison AS, Eghbalnia HR, Powers R, Raftery D, Wishart DS (2017) The future of NMR-based metabolomics. Curr Opin Biotechnol 43: 34-40. doi: 10.1016/j.copbio.2016.08.001

Martinez-Avila JC, Garcia Bartolome A, Garcia I, Dapia I, Tong HY, Diaz L, Guerra P, Frias J, Carcas Sansuan AJ, Borobia AM (2018a) Pharmacometabolomics applied to zonisamide pharmacokinetic parameter prediction (vol 14, 70, 2018). Metabolomics 14. doi: 10.1007/s11306-018-1378-0

Martinez-Avila JC, Garcia-Bartolome A, Garcia I, Dapia I, Tong HY, Diaz L, Guerra P, Frias J, Carcas Sansuan AJ, Borobia AM (2018b) Pharmacometabolomics applied to zonisamide pharmacokinetic parameter prediction. Metabolomics 14. doi: 10.1007/s11306-018-1365-5

McPhail MJW, Shawcross DL, Lewis MR, Coltart I, Want EJ, Antoniades CG, Veselkov K, Triantafyllou E, Patel V, Pop 0, Gomez-Romero M, Kyriakides M, Zia R, Abeles RD, Crossey MME, Jassem W, O'Grady J, Heaton N, Auzinger G, Bernal W, Quaglia A, Coen M, Nicholson JK, Wendon JA, Holmes E, Taylor-Robinson SD (2016) Multivariate metabotyping of plasma predicts survival in patients with decompensated cirrhosis. Journal of Hepatology 64: 1058-1067. doi: 10.1016/j.jhep.2016.01.003

Miolo G, Muraro E, Caruso D, Crivellari D, Ash A, Scalone S, Lombardi D, Rizzolio F, Giordano A, Corona G (2016) Phamacometabolomics study identifies circulating spermidine and tryptophan as potential biomarkers associated with the complete pathological response to trastuzumab-

Everett Pharmacometabonomics: Handbook of Experimental Pharmacology 100 Page 36 
paclitaxel neoadjuvant therapy in HER-2 positive breast cancer. Oncotarget. doi: 10.18632/oncotarget.9489

Nam HW, Karpyak VM, Hinton DJ, Geske JR, Ho AMC, Prieto ML, Biernacka JM, Frye MA, Weinshilboum RM, Choi DS (2015) Elevated baseline serum glutamate as a pharmacometabolomic biomarker for acamprosate treatment outcome in alcohol-dependent subjects. Translational Psychiatry 5. doi: $10.1038 /$ tp.2015.120

Navarro SL, Randolph TW, Shireman LM, Raftery D, McCune JS (2016) Pharmacometabonomic Prediction of Busulfan Clearance in Hematopoetic Cell Transplant Recipients. Journal of Proteome Research 15: 2802-2811. doi: 10.1021/acs.jproteome.6b00370

Neavin D, Kaddurah-Daouk R, Weinshilboum R (2016) Pharmacometabolomics informs pharmacogenomics. Metabolomics 12. doi: 10.1007/s11306-016-1066-x

Ni Y, Zhao L, Yu H, Ma X, Bao Y, Rajani C, Loo LM, Shvetsov YB, Yu H, Chen T, Zhang Y, Wang C, Hu C, Su M, Xie G, Zhao A, Jia W, Jia W (2015) Circulating Unsaturated Fatty Acids Delineate the Metabolic Status of Obese Individuals. Ebiomedicine 2: 1513-1522. doi: 10.1016/j.ebiom.2015.09.004

Nicholson JK, Darzi A, Holmes E, Lindon JC, Editors (2016) Metabolic phenotyping in personalized and public healthcare. Academic Press, London

Nicholson JK, Wilson ID, Lindon JC (2011) Pharmacometabonomics as an effector for personalized medicine. Pharmacogenomics 12: 103-11. doi: 10.2217/pgs.10.157

Oh J, Yi S, Gu N, Shin D, Yu K-S, Yoon SH, Cho J-Y, Jang I-J (2018) Utility of Integrated Analysis of Pharmacogenomics and Pharmacometabolomics in Early Phase Clinical Trial: A Case Study of a New Molecular Entity. Genomics \& Informatics 16: 52-58. doi: 10.5808/gi.2018.16.3.52

Park J-E, Jeong G-H, Lee I-K, Yoon Y-R, Liu K-H, Gu N, Shin K-H (2018) A Pharmacometabolomic Approach to Predict Response to Metformin in Early-Phase Type 2 Diabetes Mellitus Patients. Molecules 23. doi: 10.3390/molecules23071579

Phapale PB, Kim SD, Lee HW, Lim M, Kale DD, Kim YL, Cho JH, Hwang D, Yoon YR (2010) An integrative approach for identifying a metabolic phenotype predictive of individualized pharmacokinetics of tacrolimus. Clin Pharmacol Ther 87: 426-36. doi: 10.1038/clpt.2009.296

Phua LC, Goh S, Tai DWM, Leow WQ, Alkaff SMF, Chan CY, Kam JH, Lim TKH, Chan ECY (2017) Metabolomic prediction of treatment outcome in pancreatic ductal adenocarcinoma patients receiving gemcitabine. Cancer Chemother Pharmacol. doi: 10.1007/s00280-017-3475-6

Phua LC, Goh S, Tai DWM, Leow WQ, Alkaff SMF, Chan CY, Kam JH, Lim TKH, Chan ECY (2018) Metabolomic prediction of treatment outcome in pancreatic ductal adenocarcinoma patients receiving gemcitabine. Cancer Chemotherapy and Pharmacology 81: 277-289. doi: 10.1007/s00280-017-3475-6

Pirmohamed M (2014) Personalized pharmacogenomics: predicting efficacy and adverse drug reactions. Annual review of genomics and human genetics 15: 349-70. doi: 10.1146/annurevgenom-090413-025419

Puskarich MA, Evans CR, Karnovsky A, Das AK, Jones AE, Stringer KA (2018) SEPTIC SHOCK NONSURVIVORS HAVE PERSISTENTLY ELEVATED ACYLCARNITINES FOLLOWING CARNITINE SUPPLEMENTATION. Shock 49: 412-419. doi: 10.1097/shk.0000000000000997

Puskarich MA, Finkel MA, Karnovsky A, Jones AE, Trexel J, Harris BN, Stringer KA (2015) Pharmacometabolomics of l-Carnitine Treatment Response Phenotypes in Patients with Septic Shock. Ann Am Thorac Soc 12: 46-56. doi: 10.1513/AnnalsATS.201409-4150C

Rahmioglu N, Le Gall G, Heaton J, Kay KL, Smith NW, Colquhoun IJ, Ahmadi KR, Kemsley EK (2011) Prediction of Variability in CYP3A4 Induction Using a Combined H-1 NMR Metabonomics and Targeted UPLC-MS Approach. Journal of Proteome Research 10: 2807-2816. doi: $10.1021 /$ pr200077n

Reverter E, Lozano JJ, Alonso C, Berzigotti A, Seijo S, Turon F, Baiges A, Martinez-Chantar ML, Mato JM, Martinez-Arranz I, La Mura V, Hernandez-Gea V, Bosch J, Garcia-Pagan JC (2019) Metabolomics discloses potential biomarkers to predict the acute HVPG response to propranolol in patients with cirrhosis. Liver international : official journal of the International Association for the Study of the Liver. doi: 10.1111/liv.14042

Rotroff DM, Shahin MH, Gurley SB, Zhu H, Motsinger-Reif A, Meisner M, Beitelshees AL, Fiehn O, Johnson JA, Elbadawi-Sidhu M, Frye RF, Gong Y, Weng L, Cooper-DeHoff RM, Kaddurah-Daouk R (2015)

Everett Pharmacometabonomics: Handbook of Experimental Pharmacology 100 Page 37 
Pharmacometabolomic Assessments of Atenolol and Hydrochlorothiazide Treatment Reveal Novel Drug Response Phenotypes. CPT: pharmacometrics \&amp; systems pharmacology 4: 66979. doi: $10.1002 / p s p 4.12017$

Salari K, Watkins H, Ashley EA (2012) Personalized medicine: hope or hype? European Heart Journal 33: 1564-1570. doi: 10.1093/eurheartj/ehs112

Scalbert A, Brennan L, Fiehn O, Hankemeier T, Kristal BS, van Ommen B, Pujos-Guillot E, Verheij E, Wishart D, Wopereis S (2009) Mass-spectrometry-based metabolomics: limitations and recommendations for future progress with particular focus on nutrition research. Metabolomics 5: 435-458. doi: 10.1007/s11306-009-0168-0

Shah RR, Smith RL (2015) Addressing phenoconversion: the Achilles' heel of personalized medicine. British Journal of Clinical Pharmacology 79: 222-240. doi: 10.1111/bcp.12441

Shahin MH, Gong Y, Frye RF, Rotroff DM, Beitelshees AL, Baillie RA, Chapman AB, Gums JG, Turner ST, Boerwinkle E, Motsinger-Reif A, Fiehn O, Cooper-DeHoff RM, Han X, Kaddurah-Daouk R, Johnson JA (2017) Sphingolipid Metabolic Pathway Impacts Thiazide Diuretics Blood Pressure Response: Insights From Genomics, Metabolomics, and Lipidomics. J Am Heart Assoc 7. doi: 10.1161/JAHA.117.006656

Shin KH, Ahn LY, Choi MH, Moon JY, Lee J, Jang IJ, Yu KS, Cho JY (2016) Urinary $6 \beta$ Hydroxycortisol/Cortisol Ratio Most Highly Correlates With Midazolam Clearance Under Hepatic CYP3A Inhibition and Induction in Females: A Pharmacometabolomics Approach. AAPS J 18: 1254-1261. doi: 10.1208/s12248-016-9941-y

Shin KH, Choi MH, Lim KS, Yu KS, Jang IJ, Cho JY (2013) Evaluation of Endogenous Metabolic Markers of Hepatic CYP3A Activity Using Metabolic Profiling and Midazolam Clearance. Clinical Pharmacology \& Therapeutics 94: 601-609. doi: 10.1038/clpt.2013.128

Sjoberg RL, Bergenheim T, Moren L, Antti H, Lindgren C, Naredi S, Lindvall P (2015) Blood Metabolomic Predictors of 1-Year Outcome in Subarachnoid Hemorrhage. Neurocritical Care 23: 225-232. doi: $10.1007 / \mathrm{s} 12028-014-0089-2$

Stebbing J, Sharma A, North B, Athersuch TJ, Zebrowski A, Pchejetski D, Coombes RC, Nicholson JK, Keun HC (2012) A metabolic phenotyping approach to understanding relationships between metabolic syndrome and breast tumour responses to chemotherapy. Annals of Oncology 23: 860-U2. doi: 10.1093/annonc/mdr347

Sun Y, Kim JH, Vangipuram K, Hayes DF, Smith EML, Yeomans L, Henry NL, Stringer KA, Hertz DL (2018) Pharmacometabolomics reveals a role for histidine, phenylalanine, and threonine in the development of paclitaxel-induced peripheral neuropathy. Breast Cancer Research and Treatment 171: 657-666. doi: 10.1007/s10549-018-4862-3

Tan GG, Zhao BB, Li YQ, Liu X, Zou ZL, Wan J, Yao Y, Xiong H, Wang YY (2017) Pharmacometabolomics identifies dodecanamide and leukotriene B4 dimethylamide as a predictor of chemosensitivity for patients with acute myeloid leukemia treated with cytarabine and anthracycline. Oncotarget 8: 88697-88707. doi: 10.18632/oncotarget.20733

Trupp M, Zhu H, Wikoff WR, Baillie RA, Zeng ZB, Karp PD, Fiehn O, Krauss RM, Kaddurah-Daouk R (2012) Metabolomics reveals amino acids contribute to variation in response to simvastatin treatment. PLoS One 7: e38386. doi: PONE-D-11-24380 [pii]

\subsection{1/journal.pone.0038386}

Wang TJ, Larson MG, Vasan RS, Cheng S, Rhee EP, McCabe E, Lewis GD, Fox CS, Jacques PF, Fernandez C, O'Donnell CJ, Carr SA, Mootha VK, Florez JC, Souza A, Melander O, Clish CB, Gerszten RE (2011) Metabolite profiles and the risk of developing diabetes. Nature Medicine 17: 448-453. doi: $10.1038 / \mathrm{nm} .2307$

Wang-Sattler R, Yu Z, Herder C, Messias AC, Floegel A, He Y, Heim K, Campillos M, Holzapfel C, Thorand B, Grallert H, Xu T, Bader E, Huth C, Mittelstrass K, Doering A, Meisinger C, Gieger C, Prehn C, Roemisch-Margl W, Carstensen M, Xie L, Yamanaka-Okumura H, Xing G, Ceglarek U, Thiery J, Giani G, Lickert H, Lin X, Li Y, Boeing H, Joost H-G, de Angelis MH, Rathmann W, Suhre K, Prokisch H, Peters A, Meitinger T, Roden M, Wichmann HE, Pischon T, Adamski J, Illig T (2012) 
Novel biomarkers for pre-diabetes identified by metabolomics. Molecular Systems Biology 8. doi: $10.1038 / \mathrm{msb} .2012 .43$

Waters E, Wang JH, Redmond HP, Wu QD, Kay E, Bouchier-Hayes D (2001) Role of taurine in preventing acetaminophen-induced hepatic injury in the rat. American Journal of PhysiologyGastrointestinal and Liver Physiology 280: G1274-G1279.

Watson DG (2013) A rough guide to metabolite identification using high resolution liquid chromatography mass spectrometry in metabolomic profiling in metazoans. Computational and structural biotechnology journal 4: 1-10. doi: 10.5936/csbj.201301005

Wehrens Re, Salek Re (2019) Metabolomics : practical guide to design and analysis, 1 st edn. Chapman and Hall/CRC Press

Weng L, Gong Y, Culver J, Gardell SJ, Petucci C, Morse AM, Frye RF, Turner ST, Chapman A, Boerwinkle E, Gums J, Beitelshees AL, Borum PR, Johnson JA, Garrett TJ, McIntyre LM, Cooper-DeHoff RM (2016) Presence of arachidonoyl-carnitine is associated with adverse cardiometabolic responses in hypertensive patients treated with atenolol. Metabolomics (Los Angel) 12. doi: 10.1007/s11306-016-1098-2

Wild CP (2012) The exposome: from concept to utility. International Journal of Epidemiology 41: 24-32. doi: $10.1093 /$ ije/dyr236

Wilson ID (2009) Drugs, bugs, and personalized medicine: pharmacometabonomics enters the ring. Proc Natl Acad Sci U S A, vol 106, United States, pp 14187-8

Wilson IDa, Everett JRe, Lindon JCe, Harris RKe NMR in pharmaceutical science, 1st edn

Winnike JH, Li Z, Wright FA, Macdonald JM, O'Connell TM, Watkins PB (2010) Use of pharmacometabonomics for early prediction of acetaminophen-induced hepatotoxicity in humans. Clin Pharmacol Ther 88: 45-51. doi: clpt2009240 [pii]

$10.1038 /$ clpt.2009.240

Wishart DS (2016) Emerging applications of metabolomics in drug discovery and precision medicine. Nature Reviews Drug Discovery 15: 473-484. doi: 10.1038/nrd.2016.32

Wishart DS, Feunang YD, Marcu A, Guo AC, Liang K, Vazquez-Fresno R, Sajed T, Johnson D, Li CR, Karu N, Sayeeda Z, Lo E, Assempour N, Berjanskii M, Singhal S, Arndt D, Liang YJ, Badran H, Grant J, Serra-Cayuela A, Liu YF, Mandal R, Neveu V, Pon A, Knox C, Wilson M, Manach C, Scalbert A (2018) HMDB 4.0: the human metabolome database for 2018. Nucleic Acids Research 46: D608D617. doi: 10.1093/nar/gkx1089

Yerges-Armstrong LM, Ellero-Simatos S, Georgiades A, Zhu H, Lewis JP, Horenstein RB, Beitelshees AL, Dane A, Reijmers T, Hankemeier T, Fiehn O, Shuldiner AR, Kaddurah-Daouk R, Pharmacometabol Res N (2013) Purine Pathway Implicated in Mechanism of Resistance to Aspirin Therapy: Pharmacometabolomics-Informed Pharmacogenomics. Clinical Pharmacology \&amp; Therapeutics 94: 525-532. doi: 10.1038/clpt.2013.119

Zhang P, Li W, Chen J, Li R, Zhang Z, Huang Y, Xu F (2017a) Branched-Chain Amino Acids as Predictors for Individual Differences of Cisplatin Nephrotoxicity in Rats: A Pharmacometabonomics Study. J Proteome Res. doi: 10.1021/acs.jproteome.7b00014

Zhang ZX, Gu H, Zhao HZ, Liu YH, Fu S, Wang ML, Zhou WJ, Xie ZY, Yu HH, Huang ZH, Gao XY (2017b) Pharmacometabolomics in Endogenous Drugs: A New Approach for Predicting the Individualized Pharmacokinetics of Cholic Acid. Journal of Proteome Research 16: 3529-3535. doi: 10.1021/acs.jproteome.7b00218

Zhu H, Bogdanov MB, Boyle SH, Matson W, Sharma S, Matson S, Churchill E, Fiehn O, Rush JA, Krishnan RR, Pickering E, Delnomdedieu M, Kaddurah-Daouk R, Network PR (2013)

Pharmacometabolomics of response to sertraline and to placebo in major depressive disorder possible role for methoxyindole pathway. PLoS One 8: e68283. doi:

10.1371/journal.pone.0068283

Everett Pharmacometabonomics: Handbook of Experimental Pharmacology 100 Page 39 